ReVISTA de BIOLOGía TROPICAL

\title{
The easternmost tropical Pacific. Part II: Seasonal and intraseasonal modes of atmospheric variability
}

\author{
Jorge A. Amador ${ }^{1,2}$, A. M. Durán-Quesada ${ }^{1,2}$, E. R. Rivera ${ }^{1,2}$, G. Mora ${ }^{1,2}$, F. Sáenz ${ }^{2}$, B. Calderón ${ }^{2}$ \\ \& N. Mora ${ }^{2}$ \\ 1. Escuela de Física, Universidad de Costa Rica, 11501-2060 San José, Costa Rica; jorge.amador@ucr.ac.cr \\ 2. Centro de Investigaciones Geofísicas, Universidad de Costa Rica, 11501-2060 San José, Costa Rica.
}

\section{Received 31-V-2015. Corrected 19-X-2015. Accepted 27-X-2015.}

\begin{abstract}
This is Part II of a two-part review about climate and climate variability focused on the Eastern Tropical Pacific (ETP) and the Caribbean Sea (CS). Both parts are aimed at providing oceanographers, marine biologists, and other ocean scientists, a guiding base for ocean-atmosphere interaction processes affecting the CS, the ETP, and the waters of Isla del Coco. Isla del Coco National Park is a Costa Rican World Heritage site. Part I analyzed the mean fields for both basins and a larger region covering $25^{\circ} \mathrm{S}-35^{\circ} \mathrm{N}, 20^{\circ} \mathrm{W}-130^{\circ} \mathrm{W}$. Here we focus on a smaller area $\left(65^{\circ} \mathrm{W}-95^{\circ} \mathrm{W}, 0^{\circ}-20^{\circ} \mathrm{N}\right)$, as a complement to Part 1 . Incoming solar radiation and surface energy fluxes reveal the complex nature of the ETP and CS for convective activity and precipitation on seasonal and intraseasonal time scales. Both regions are relevant as sources of evaporation and the associated moisture transport processes. The American Monsoon System influences the climate and climate variability of the ETP and CS, however, the precise way systems affect regional precipitation and transport of moisture, within the Intra Americas Sea (IAS) are not clear. Although the Caribbean Low-Level Jet (CLLJ) is known to act as a conveyor belt for moisture transport, intraseasonal and seasonal modes of the CLLJ and their interactions with other IAS systems, have to be further investigated. Trans-isthmic jets, exert a variable seasonal wind stress force over the ocean surface co-generating regions of great marine productivity. Isolated convection, the seasonal migration of the Intertropical Convergence Zone, the hurricane season, the Mid-Summer Drought, the seasonal and intraseasonal behavior of low-level jets and their interactions with transients, and the southward incursion of cold fronts contribute to regional seasonal precipitation. Many large-scale systems, such as El Niño-Southern Oscillation, the Atlantic Multidecadal Oscillation and the Madden-Julian Oscillation (MJO, also influence the variability of precipitation by modulating regional features associated with convection and precipitation. Monthly tropical storm (TS) activity in the CS and ETP basins is restricted to the period May-November, with very few cases in December. The CS presents TS peak activity during August, as well as for the number of hurricanes and major hurricanes, in contrast to the ETP that shows the same features during September. Rev. Biol. Trop. 64 (Suppl. 1): S23-S57. Epub 2016 Febrary 01.
\end{abstract}

Key words: Cocos Island, Isla del Coco, seasonal and intraseasonal variability modes, Madden-Julian Oscillation, Caribbean Low-Level Jet, Chocó Jet, trans-isthmic low-level jets, atmospheric rivers.

The Intra Americas Sea (IAS) is defined here as a region comprising the Gulf of Mexico (GM), the Caribbean Sea (CS), the Easternmost Tropical Pacific (ETP) and embedded continental areas. The dominant rain-producing systems of this tropical region are primarily convective in nature, however, their origin may be very broad. Convection may be the result of land and sea breeze processes, direct solar heating, wind-topography interactions, tropical waves, and tropical cyclones, among other processes. The region is also affected by systems coming from mid and high latitudes, including cold fronts and "temporales", periods of light to moderate rainfall lasting several days over a synoptic scale domain (Hastenrath, 1991; Amador, Chacón, \& Laporte, 2003). Most of the above systems are present in both the CS 
and the ETP and provide a mean of interaction between these two water bodies within the IAS. This study is Part II of Amador et al. (2016). In Part I, mean atmospheric and oceanic features of the ETP and parts of the Atlantic Ocean were discussed for the area $25^{\circ} \mathrm{S}-35^{\circ} \mathrm{N}, 20^{\circ} \mathrm{W}-130^{\circ} \mathrm{W}$. In addition, major atmospheric low frequency modes of variability, such as the El Niño-Southern Oscillation (ENSO), the Pacific Decadal Oscillation (PDO) and the Atlantic Multi-decadal Oscillation (AMO) were examined, pointing out their interactions with other atmospheric systems, including the way they modulate precipitation and wind, and their association with annual tropical cyclone frequencies.

The objectives and framework of this research are also those of Amador et al. (2016). This part is dedicated to review seasonal and intraseasonal modes of atmospheric variability on the ETP and CS regions. Tropical intraseasonal variability of atmospheric and oceanic variables significantly impacts atmospheric state in these regions. As a complementary objective, this work is also aimed at constructing a data base for future climate change studies based on the smaller domain (part of the ETP, including Coco's Island waters, and the Caribbean basin). The integral objectives of this work and its companion are in accordance with the framework of the project "Consejo Nacional de Rectores (CONARE): Interacciones océano-atmósfera y la biodiversidad marina de la Isla del Coco, Costa Rica", in order for oceanographers, marine biologists, ecologists, and other ocean and atmospheric scientists, to have a guiding base for most ocean-atmospheric interaction processes affecting, among others, the waters of the Coco's Island. This island is a World Heritage site of Costa Rica, with one of the highest concentration hotspots of biodiversity and endemics per unit area of the Indo-Pacific (Allen, 2008).

Atmospheric systems impacting the IAS and affecting the ETP and CS are reviewed so that the atmospheric connection between the two oceans (Atlantic and Pacific) and parts of the IAS can be discussed and highlighted. In the next section data and procedures used here are provided, followed by a review of the seasonal oceanic and atmospheric components of IAS climate. Surface incoming solar radiation, sensible, latent and net surface heat fluxes are analyzed and linked with patterns of atmospheric variables. The ETP and CS wind fields are emphasized as major contributors to ocean motion and associated dynamical and chemical properties. Low-level jets affecting the ETP$\mathrm{CS}$ are also discussed (Caribbean Low-level Jet, CLLJ; Chocó Jet, CJ; and trans-isthmic jets, TJs) along with the seasonal distribution of evaporation and precipitation patterns. A Sidebar is appended to briefly discuss atmospheric rivers (a significant atmospheric feature relevant to regional climate) and their potential connections with the CS, the ETP and midlatitudes. The following section in this article is devoted to depict intraseasonal modes (10 to 30 day high frequency oscillations, and the 30-90 day or so Madden-Julian Oscillation, MJO), and their relationship with precipitation. This approach follows approximately the categorization used by Serra et al. (2014) when discussing tropical intraseasonal modes of the atmosphere. The last section of this work depicts the tropical cyclone (TC) monthly frequency distribution as a function of hurricane intensity or status for both basins since 1965, when meteorological satellites started to be used for this purpose. Finally, in the last section, a summary and final remarks for future research are presented.

\section{Data and procedures}

The region of analysis is defined here as $65^{\circ} \mathrm{W}-95^{\circ} \mathrm{W}, 0^{\circ}-20^{\circ} \mathrm{N}$, and covers part of the IAS (see, Fig. 1 of Part I). Radiation, latent and sensible heat fluxes, net surface energy flux, and evaporation data used, are from the Objectively Analyzed Air-sea Fluxes (OAFlux) Project (Yu, Jin, \& Weller, 2008). Surface fluxes used here did not show any significant differences with those of Tropflux over the analysis area (not shown). Besides that, Kumar, Vialard, 

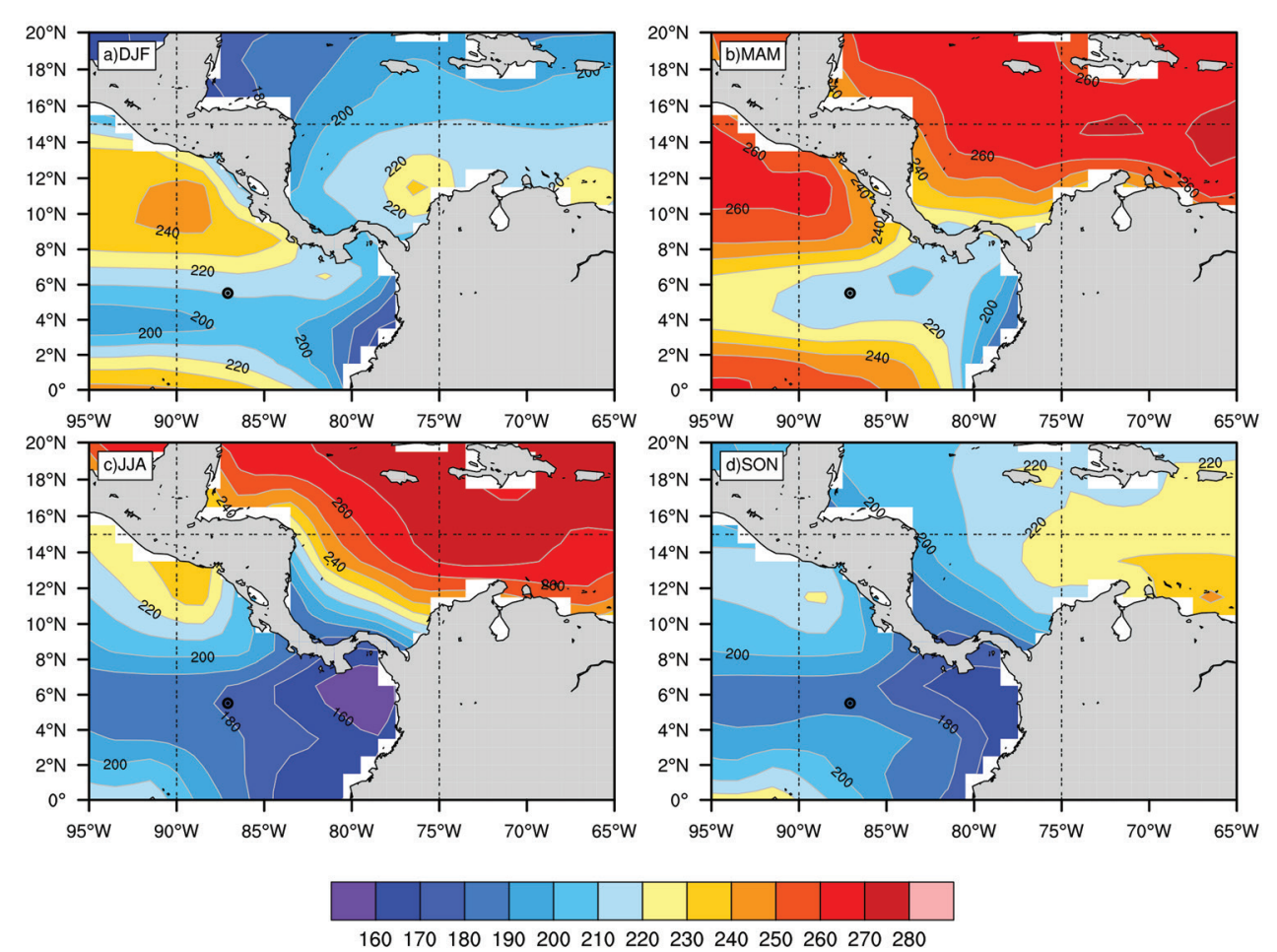

$\left(\mathrm{W} \mathrm{m}^{-2}\right)$

Fig. 1. Seasonal distribution of surface incoming short wave radiation ( $\mathrm{W} \mathrm{m}^{-2}$ ) for (a) December-January-February (DJF), (b) March-April-May (MAM), (c) June-July-August (JJA) and (d) September-October-November (SON).

Lengaigne, Murty \& McPhaden (2012) in an evaluation of several data sets of air-sea fluxes for the global tropical oceans, reported the OAFlux and Tropflux performed best. Sea surface temperature (SST) information was retrieved from both, the OAFlux Project, and the National Oceanic and Atmospheric Administration (NOAA) Optimum Interpolation (OI) 0.25-degree daily SST analysis (Reynolds et al., 2007). Precipitation comes from the Tropical Rainfall Measuring Mission (TRMM) version 7 (3B42; Huffman et al., 2007). Salinity at 5-meter depth from the Simple Ocean Data Assimilation (SODA) dataset (Carton, \& Giese, 2008) is obtained from http://iridl.ldeo. columbia.edu. Surface pressure data is from the publicly available global ERA (European Reanalysis)-Interim Reanalysis (Dee et al., 2011). The Cross-Calibrated Multi-Platform
(CCMP) Ocean Surface Vector Analysis data was used to analyze monthly winds. The revised hurricane database (HURDAT2) from the National Hurricane Center (NHC) provided the time series of tropical cyclone frequency and intensity for the ETP and Caribbean basins. All data used in this study are described in more detail in Table 1 of Amador et al. (2016).

\section{Seasonal and intraseasonal oceanic and atmospheric variability}

\subsection{Radiation and surface energy fluxes}

The surface energy fluxes are defined here as positive if downward (ocean heat gain). The net surface heat flux (NS) is the sum of the net shortwave (SW) radiation, the latent and the sensible heat fluxes and the net longwave radiation (not shown in this study). 
The seasonal distribution of SW radiation (Figs. 1a to d) clearly shows the relative migration of solar heating into both hemispheres. Over parts of the ETP and CS, radiation exceeds $200 \mathrm{Wm}^{-2}$ year round with maxima in March-April-May (MAM) in both basins (Fig. $1 \mathrm{~b})$. A minimum of solar radiation is found from $6-8^{\circ} \mathrm{N}$ over the ETP in June-July-August (JJA, Fig. 1c), extending to September-October-November (SON, Fig. 1d). This reflects, to some extent, the effect of the cloud tops associated with the northward migration of the InterTropical Convergence Zone (ITCZ). The ETP presents a maximum west of northern Central America during summer, while the Caribbean shows maximum regional values of more than $260 \mathrm{Wm}^{-2}$ during the same season. The CS maximum, as is shown in Section 2.6 below, is associated with a minimum in regional precipitation. The Western Hemisphere Warm Pool (WHWP, Wang \& Enfield, 2001; 2003),
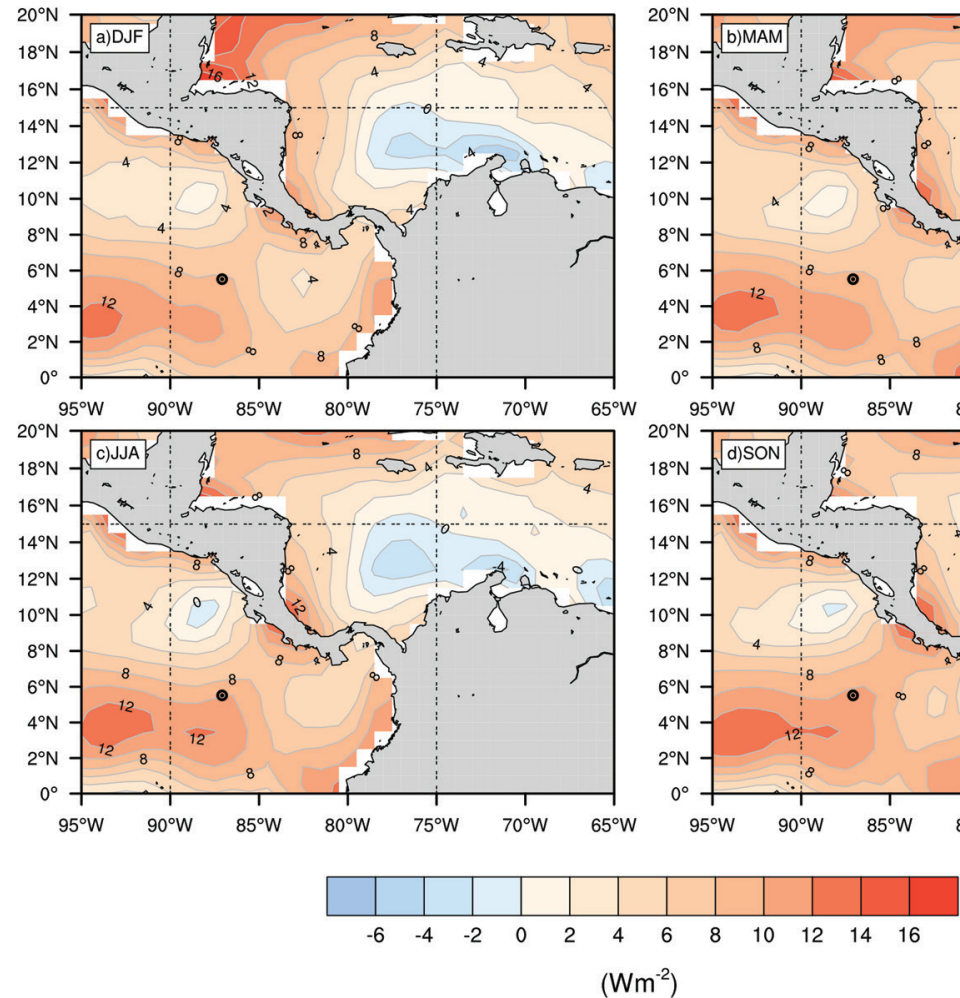

$\left(\mathrm{Wm}^{-2}\right)$

Fig. 2. Seasonal distribution of sensible heat flux $\left(\mathrm{W} \mathrm{m}^{-2}\right)$ for (a) December-January-February (DJF), (b) March-April-May (MAM), (c) June-July-August (JJA) and (d) September-October-November (SON). See text for definition of net surface energy flux. 
order (denoted a, b, c and d, as in Fig. 1). As can be observed in these figures, sensible heat flux is, as expected, one order of magnitude smaller than latent heat (Fig. 3), however, it also contributes significantly to favor convective activity (Chen, Li, \& He, 2012). Minimum values of sensible heat flux all year round are found over a large portion of the CS and west of Costa Rica. The former region, located northward of the Colombia and Venezuela coasts, is characterized by strong upwelling, while the latter is connected with the Costa Rica Dome (Umatani, \& Yamagata, 1991; Fiedler, 2002; Alfaro, \& Cortés, 2012). Negative sensible heat flux is associated with the cooling of the ocean surface not only due to thermal differences between the sea surface and the air above, where heat transfer is affected by surface wind speed. In JJA the extension of the CLLJ into the Pacific coast near the Gulf of Papagayo (see below), can partially explain the surface cooling and negative values of sensible heat flux. Seasonal latent heat flux (Figs. $3 a$ to d) presents minimum values over most of the ETP adjacent to Central America, in contrast to the CS that shows fluxes in excess of $100 \mathrm{Wm}^{-2}$ most of the year. The availability of latent heat in the Caribbean is a potential source of moisture for Central America and the IAS as a whole (Durán-Quesada, Gimeno, Amador, \& Nieto, 2010). In the CS, precipitation is relatively meager, except in its westernmost side near Central America, partly due to the role of the CLLJ, as a large-scale forcing mechanism (Amador, 2008). Over the ETP, minimum values are observed all year round, except west of $85^{\circ} \mathrm{W}$ and near SA. The latter region is known to be a source for moisture transport toward Central America, especially during boreal autumn (Durán-Quesada et al.,
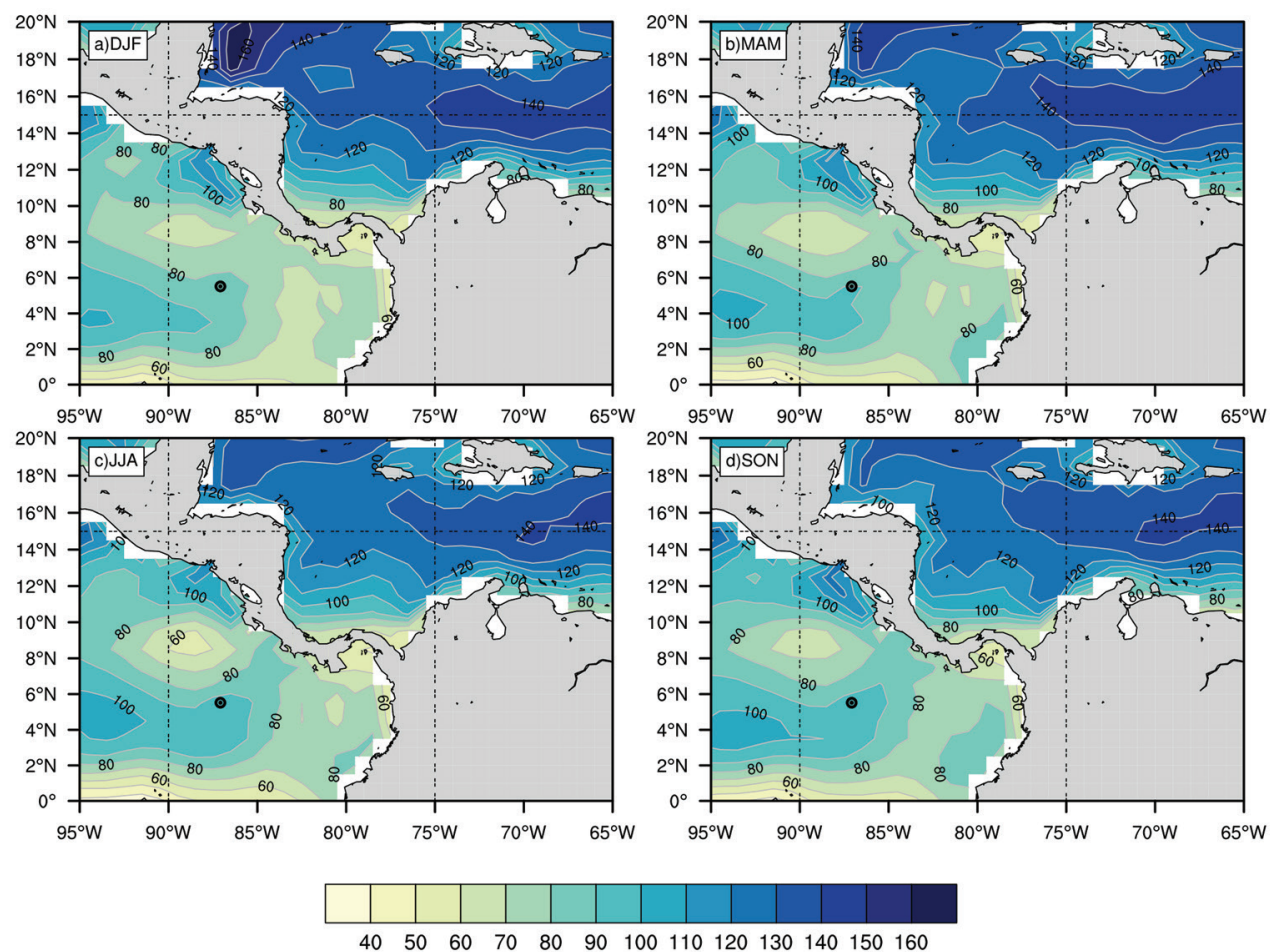

$\left(\mathrm{Wm}^{-2}\right)$

Fig. 3. Seasonal distribution of latent heat flux $\left(\mathrm{W} \mathrm{m}^{-2}\right)$ for (a) December-January-February (DJF), (b) March-April-May (MAM), (c) June-July-August (JJA) and (d) September-October-November (SON). See text for definition of net surface energy flux. 
2010). See also Section 2.6 on monthly precipitation distribution.

The NS shows a marked annual cycle (Figs. 4a to d). December-January-February (DJF) mean (Fig. 4a) presents a positive structure just below $10^{\circ} \mathrm{N}$ and $90^{\circ} \mathrm{W}$. Although not shown here, the northern Caribbean, the GM and north Atlantic show negative values for NS flux with maximum intensity east of the GM and over the region of the Gulf Stream (Amador et al., 2016). MAM is a transition season with primarily positive NS flux values over the analysis area (Fig. 4b). Although there is positive NS during this season, precipitation is mostly confined to the ITCZ, which is slowly moving northward at this time. Large positive NS is observed in the CS and part of the Atlantic (Fig. 4c) during JJA. The absolute maximum NS is found just south of the Equator. For SON (Fig. 4d) the NS over the Atlantic decreases to negative values especially over the GM.

\subsection{Sea surface temperature, sea level pressure and salinity}

The monthly SST distribution, using the OI dataset is represented in Figure 5. The tropics receive a maximum of incoming solar radiation (of the order of $240 \mathrm{Wm}^{-2}$ ), and SST is particularly warm in the vicinity of the CS and the GM. The WHWP has been defined as enclosed by the $28.5^{\circ} \mathrm{C}$ isotherm (Wang, \& Enfield, 2001), so, the solid black line, in all panels of Figure 5, denotes that isotherm. The WHWP corresponds to the second largest warm water body after the Indo-Pacific Warm Pool (Wang, \& Enfield, 2001; 2003). The WHWP has a marked seasonal cycle in which warmer temperatures are phased sequentially from the Eastern North Pacific (ENP) and west
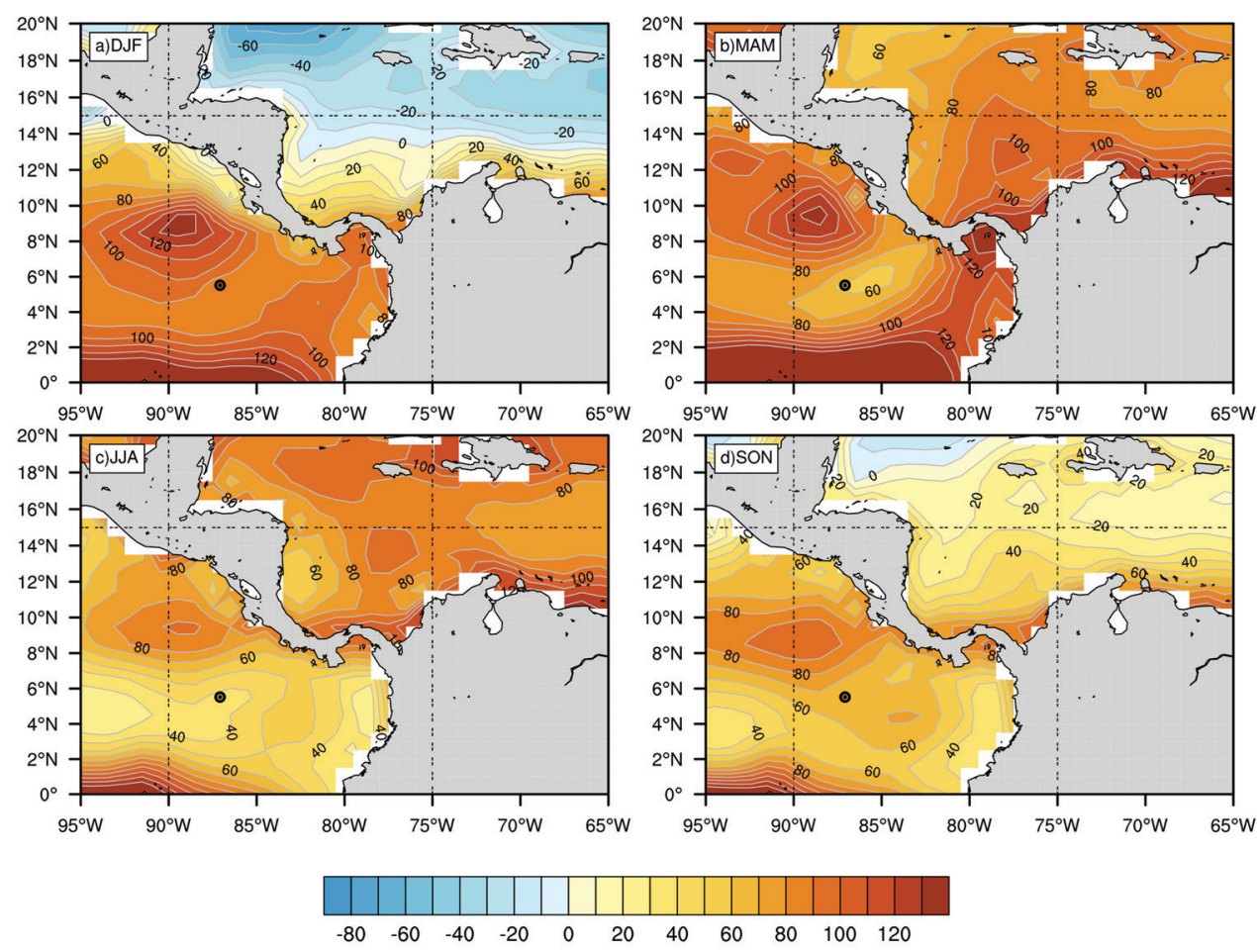

$\left(\mathrm{Wm}^{-2}\right)$

Fig. 4. Seasonal distribution of net surface energy flux $\left(\mathrm{W} \mathrm{m}^{-2}\right)$ for (a) December-January-February (DJF), (b) MarchApril-May (MAM), (c) June-July-August (JJA) and (d) September-October-November (SON). See text for definition of net surface energy flux. 


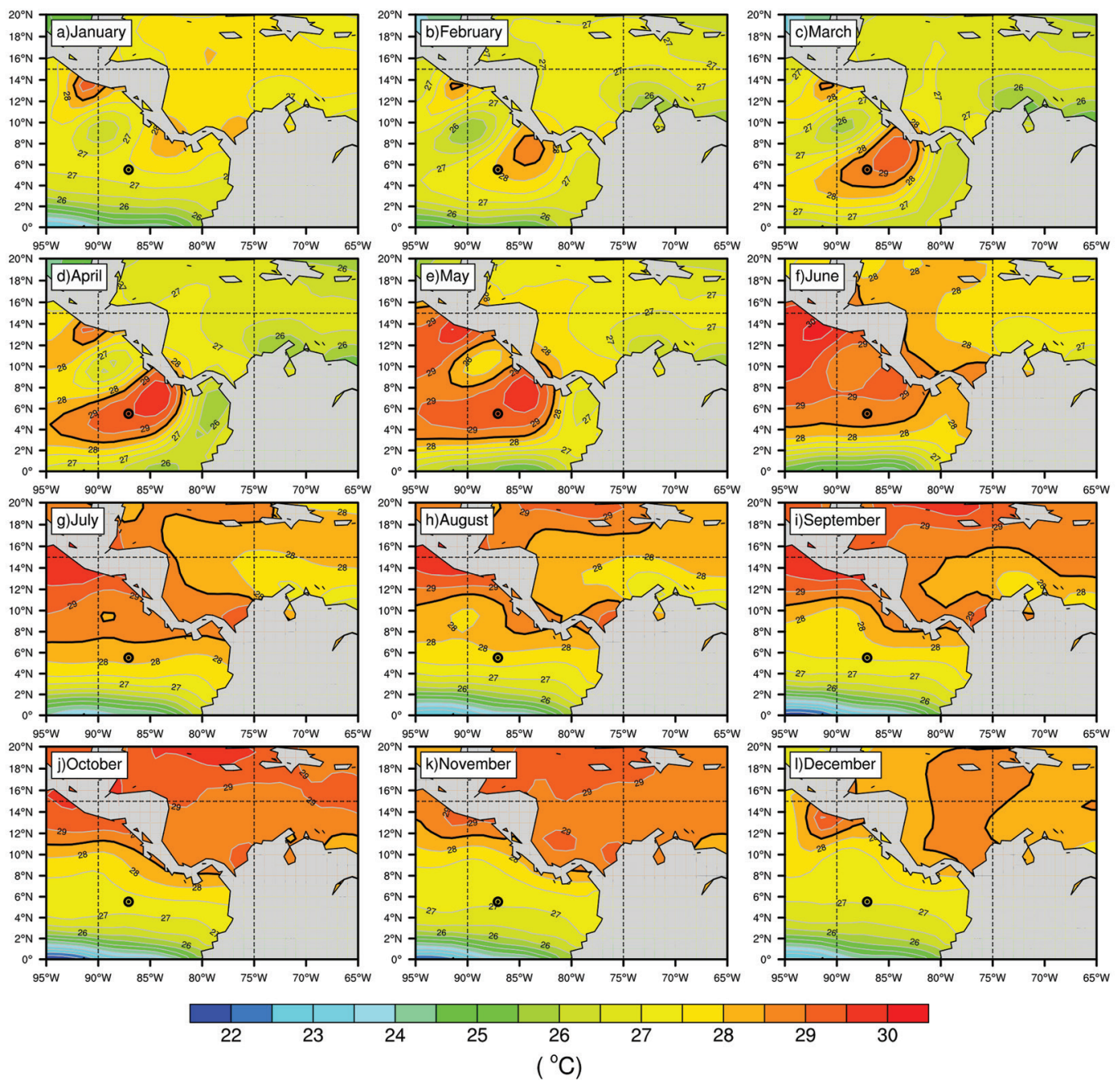

Fig. 5. Monthly climatology of sea surface temperatures $\left({ }^{\circ} \mathrm{C}\right)$ using the OISST dataset.

of Central America to the rest of the IAS. The structure extends along the western Tropical North Atlantic (TNA) following the description by Wang \& Enfield (2001). According to Wang \& Enfield (2003), there is an important link between seasonal variations in tropospheric heat and moisture over tropical Americas and the development of the WHWP. Moreover, the WHWP anomalies have a significant impact on the development of tropical convection (Wang, Enfield, Lee, \& Landsea, 2006). The WHWP is comprised of the Eastern Pacific Warm Pool (EPWP) to the west of the land bridge and the Atlantic Warm Pool (AWP) to the east, as observed in Figs. 5d to 1. The AWP has been shown to be important for the IAS on both seasonal and interannual time scales (Wang et al., 2006). The AWP has the potential to influence local winds, precipitation and tropical cyclone development (Wang, \& Lee, 2007). Using observations, Wang et al. (2006) show a relationship between variations in the AWP and the vertical wind shear that may affect the Atlantic hurricane activity. The above results may have another explanation according to Amador (2008), since the CLLJ can also force the observed meridional SST gradient, due to 
Ekman pumping equatorward of the jet core (Figs. $5 \mathrm{f}$ to $\mathrm{i}$ and Sec. 2.4 below).

The period between summer and autumn is of particular importance since the AWP is fully developed (Figs. 5f to k). The AWP relevance for climate in the IAS, as well as interactions with the CLLJ and convective systems, has been extensively studied. The role of the AWP for the climate system goes beyond regional interactions since Atlantic variability has been proposed to affect global atmospheric circulation (Wang, \& Enfield, 2003). The WHWP is also important to moisture availability due to the enhancement of evaporation over this region. The AWP is known to play a role as a source of moisture (Gimeno, Drumond, Nieto, Trigo, \& Stohl, 2010; Gimeno et al., 2011) and modulate moisture transport to Central America (Durán-Quesada et al., 2010). Moreover, the relationship between warmer SSTs and regional winds is key for moisture transport processes. The SST is also fundamental to atmosphereocean interactions and marine processes (e.g., evaporation and ocean productivity).

On the EPWP, SST conditions vary on much shorter time scales, some of which have been associated with a disruption of the annual cycle of precipitation on the Pacific side of Central America and southern Mexico known as the Mid-Summer Drought or MSD (Magaña, Amador, \& Medina, 1999). The MSD also varies on intraseasonal time scales (Amador, 2008; Fig. 3), a multi-scale factor that is far from being understood.

Important differences on the order of $1^{\circ} \mathrm{C}$ (Figs. 6a to d) were found in the two cited SST products (OAFlux SST and OI SST), with the summer and autumn months tending to show the smallest differences (Figs. 6g to $\mathrm{j}$ ). The differences in SST data sets shown in Figure 6 have significant implications for defining the components and evolution of the WHWP using the $28.5^{\circ} \mathrm{C}$ isotherm. Also, over the Caribbean, differences in the north-south SST gradient estimated with these two datasets may have important implications for the interpretation of the ocean-atmosphere energy budgets and the wind-shear and associated cyclone activity, as discussed by Wang et al. (2006).
The three-month averages of mean sea level pressure (MSLP) have a marked seasonal intensification of the Azores High in boreal winter (not shown here, see Fig. 6 of Amador et al., 2016). During DJF (Fig. 7a), the MSLP distribution is characterized by a strong meridional pressure gradient. At this time, cold weather systems from the Northern Hemisphere (NH) penetrate south into the tropics (cold fronts). During DJF and MAM (Fig. 7b) the Pacific High (see Fig. 6 of Amador et al., 2016) is also well developed, with the difference that during MAM the high pressure over continental North America shifts southward. As observed in JJA (Fig. 7c), the Azores high also exhibits a maximum. At the same time, the Pacific High is weakened and the low pressure over the Pacific enhances the east-west pressure gradient. SON (Fig. 7d), a period of intense regional precipitation, presents low pressures over almost the whole region.

Monthly salinity distributions (Fig. 8) show, in general terms, a structure characterized by a more saline CS in comparison with the ETP. However, the evolution of the salinity patterns show a marked annual cycle over the ETP, in contrast to the CS. During DJF (Figs. $8 \mathrm{a}$ to $\mathrm{c}$ ), the minimum of salinity is located in the west coast of southern Colombia and Ecuador. Some rivers in Colombia, such as the San Juan and Baúdo have fresh water discharges of 82.1 and $23.7 \mathrm{~km}^{3}$ year-1 (Restrepo, \& Kjerfve, 2004), respectively, partially explaining the minimum of salinity in that region. A remarkable increase in salinity over the ETP is observed from April to June (Figs. $8 \mathrm{~d}$ to $\mathrm{f}$ ) and during the second part of the rainy season in Central America (Figs. 8h to k), suggesting an increase in evaporation associated with the ITCZ migration.

\subsection{Wind fields}

\subsubsection{Regional Monsoons and Trades}

\section{The American Monsoon System}

A monsoon-type pattern in North and South America is featured by the seasonal 

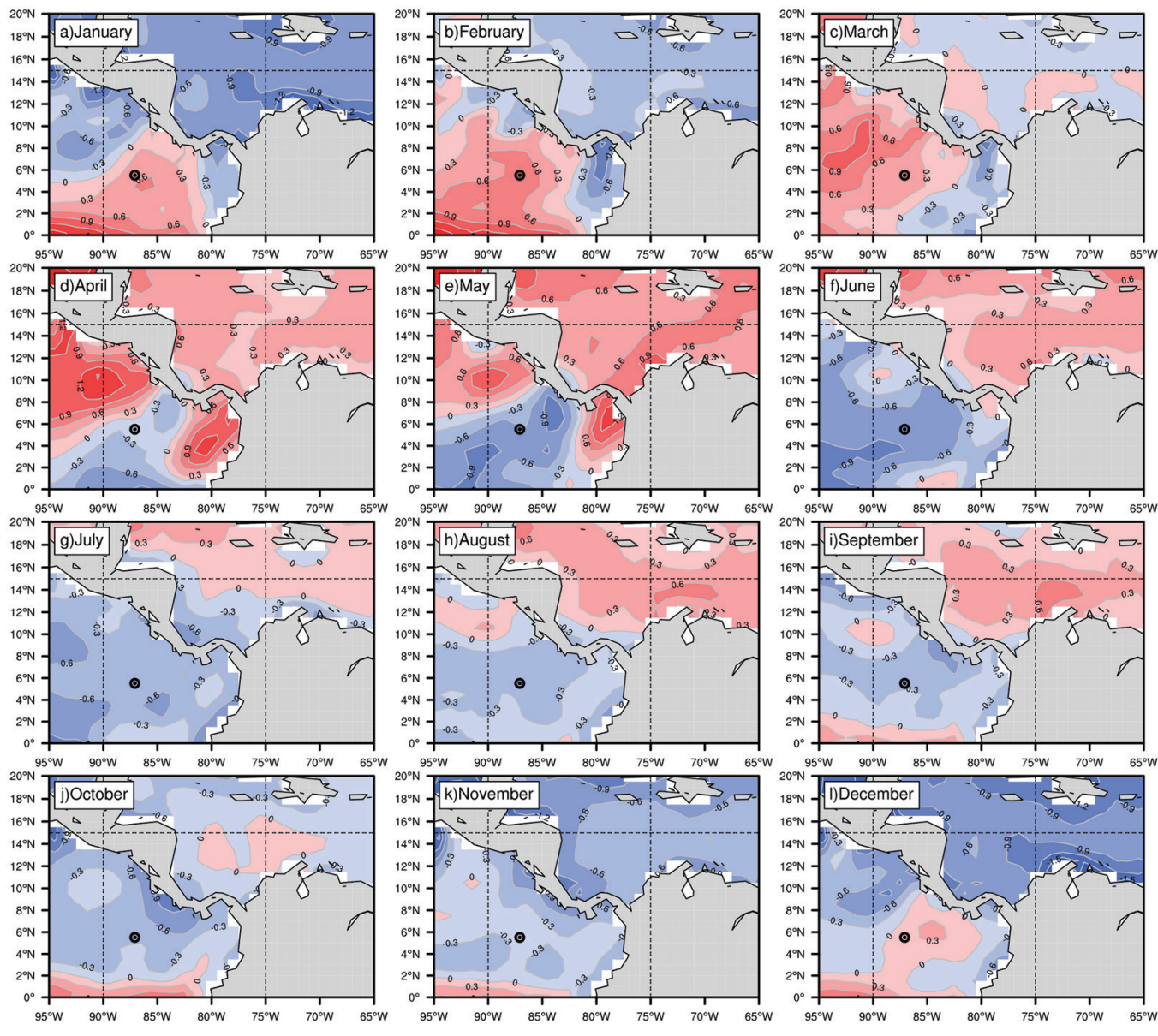

$\begin{array}{llllllllll}95^{\circ} \mathrm{W} & 90^{\circ} \mathrm{W} & 85^{\circ} \mathrm{W} & 80^{\circ} \mathrm{W} & 75^{\circ} \mathrm{W} & 70^{\circ} \mathrm{W} & 65^{\circ} \mathrm{W}\end{array}$

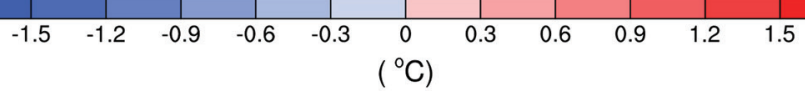

Fig. 6. Monthly sea surface temperature differences $\left({ }^{\circ} \mathrm{C}\right)$ between OAFlux and OISST datasets.

distribution of surface pressure and low-level inflow of oceanic moisture (Mechoso, Robertson, Ropelewski, \& Grimm, 2005). The distribution of precipitation showing marked seasonal peaks is considered as an indicator of such monsoon-like circulations in the Americas (Vera et al., 2006). Those seasonal circulations and precipitation distributions have been identified as a regional monsoon system (Maddox, McCollum, \& Howard, 1995; Adams, \& Comrie, 1997) and named the American Monsoon System (AMS). The AMS is comprised of two individual systems located in the $\mathrm{NH}$ and
Southern Hemisphere (SH) of the Americas. A brief description of both the North American Monsoon System (NAMS) and South American Monsoon System (SAMS) is provided below, focused on the main features of the NAMS due to its dynamical influence on the IAS weather and climate.

The NAMS is characterized by intense precipitation over northwestern Mexico and the southwestern United States (US). Summer rainfall in northwestern Mexico and the southern US has a large dependence on the NAMS. Douglas, Maddox, Howard \& Reyes 

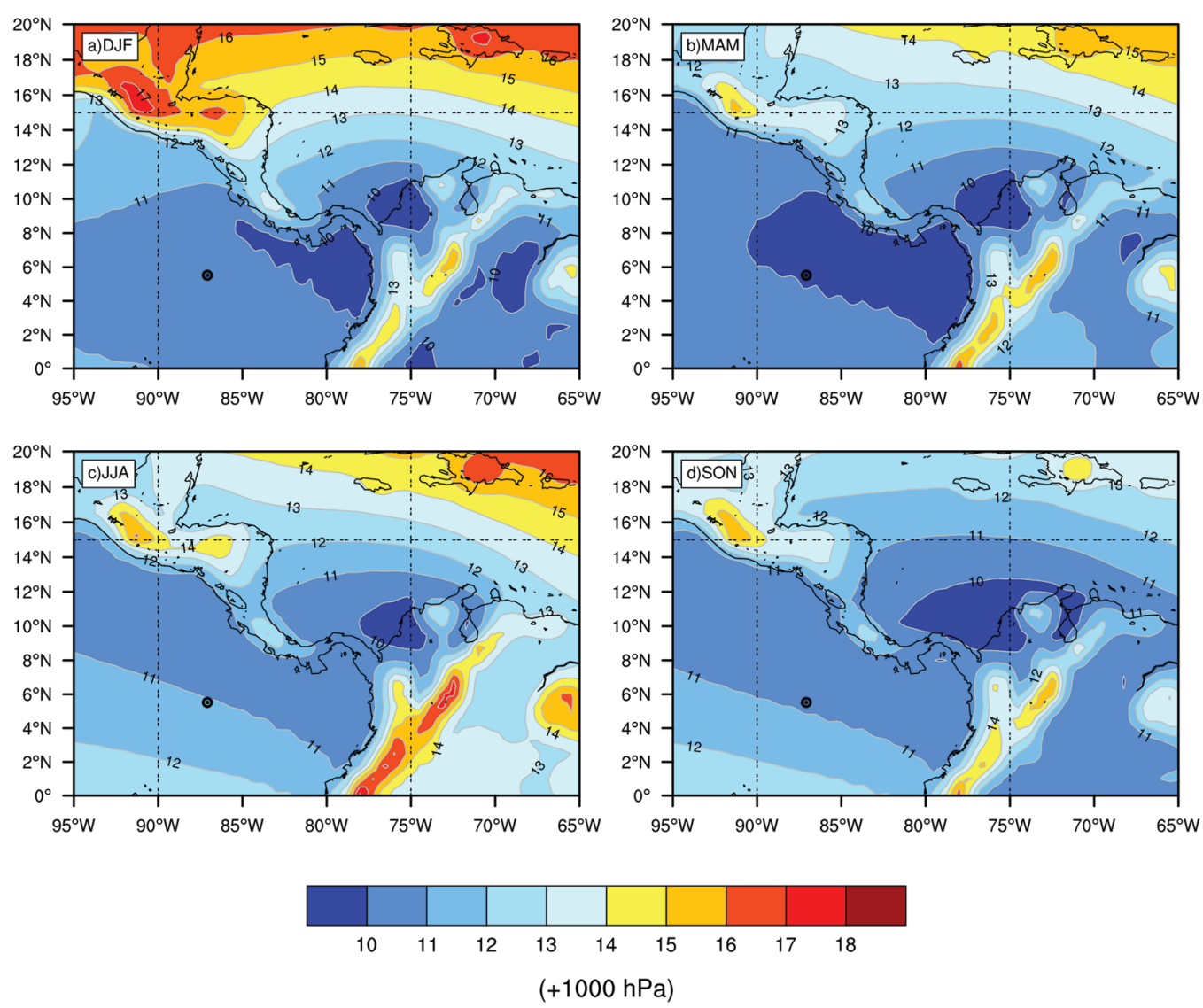

Fig. 7. Seasonal distribution of mean sea level pressure (+1000 hPa) for (a) December-January-February (DJF), (b) MarchApril-May (MAM), (c) June-July-August (JJA) and (d) September-October-November (SON).

(1993), point out that for those regions the NAMS linked precipitation contributes up to $40 \%$ of summer rainfall, meanwhile in some regions of Mexico, rainfall associated with the NAMS can contribute up to $70 \%$ of the annual rainfall. The reversed thermal contrast is also an important component of the monsoon over water (Ropelewski, Gutzler, Higgins, \& Mechoso, 2005) and complex orography over the southwestern US and Mexico together with the upper-level lows enhance precipitation in these regions.

During the pre-development of the NAMS, the low-level circulation is characterized by easterly and south-easterly low-level winds which enhance the transport of moisture (Higgins, Yao, \& Wang, 1997) and gulf surges up the Gulf of California (Fuller, \& Stensrud, 2000). Observations, reanalysis and modeling studies have been used to determine the origin of the moisture (Schmitz, \& Mullen, 1996; Higgins et al., 1997; Castro, McKee, \& Pielke, 2001; Bosilovich, Sud, Schubert, \& Walker, 2003). The dominant sources of monsoon precipitation are the result of local continental evaporation and transport from adjacent oceanic regions. Moisture for the NAMS development is supplied by the GM, CS, Pacific Ocean and the Gulf of California, so that these are the major oceanic components for the NAMS onset (see for example $\mathrm{Hu}$, \& Domínguez, 2015). The reference observational study of the NAMS is the North American Monsoon Experiment, NAME, (Higgins et al., 2006). 

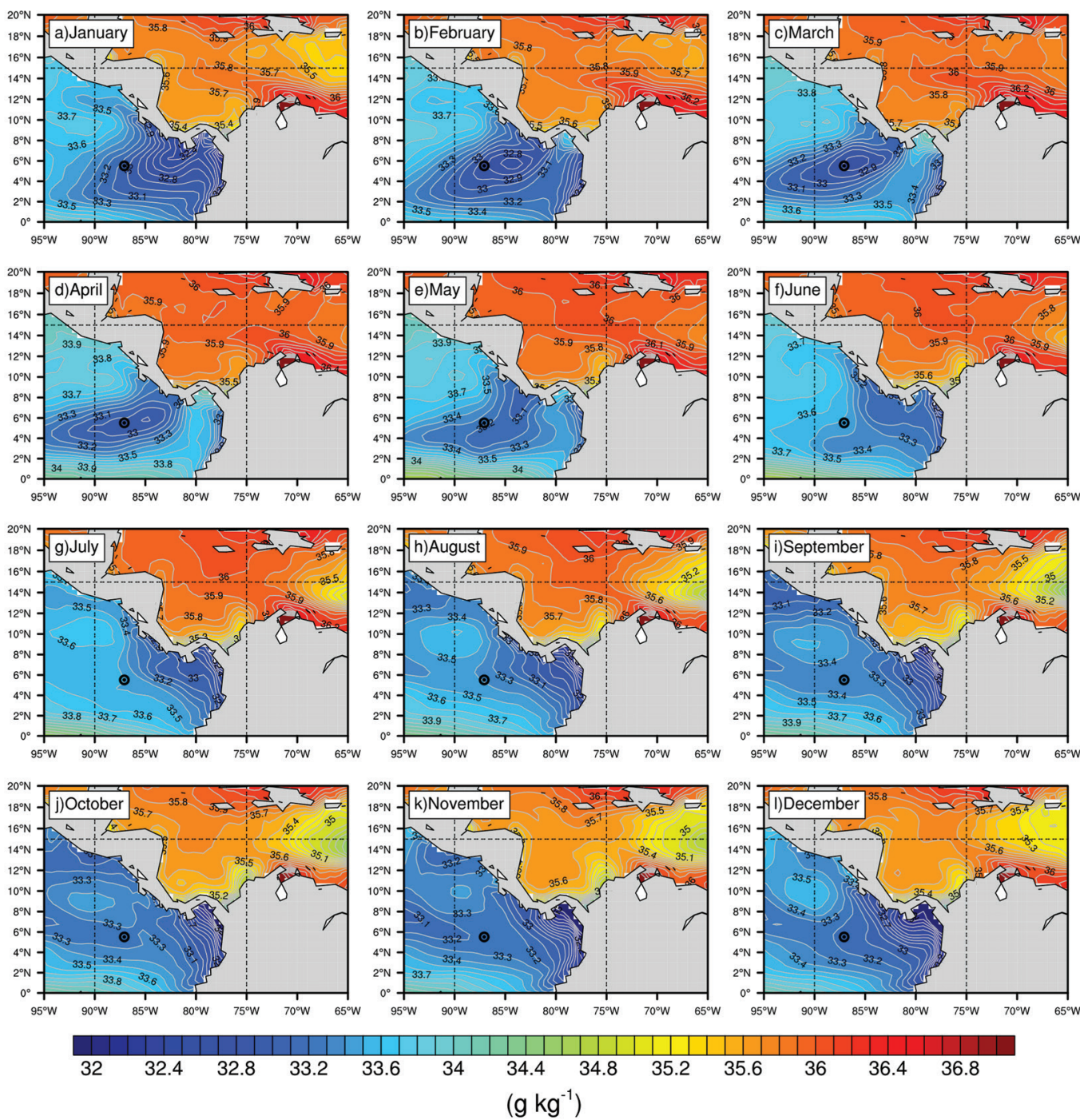

Fig. 8. Monthly climatology of salinity at $5 \mathrm{~m}$ depth $\left(\mathrm{g} \mathrm{kg}^{-1}\right)$.

This experiment provided a large dataset of observations to study the components of the NAMS (Higgings, \& Gochis, 2007). The modeling strategy was useful in the improvement of the ability in the simulation and prediction of monsoon precipitation (Gochis, Shuttleworth, \& Yang, 2002). Moisture transport has been extensively discussed in studies such as those of Mestas-Núñez, Enfield \& Zhang (2007) and Wang (2007), which highlight the importance of the moisture transport from the $\mathrm{CS}$ and GM as well as the relationship between the Great Planes Low-Level Jet (GPLLJ) and the NAMS. Mo, Chelliah \& Carrera (2005) proposed a connection amongst the GPLLJ, the CLLJ and moisture transport. Moreover, transport from the CS and related transport mechanisms are then crucial to understand the evolution of the NAMS.

The SAMS is defined by intense precipitation mainly over Central Brazil and Bolivia (Mechoso et al., 2005). The low-level jets moisture transport that favors the development of the monsoon circulation and the intensification 

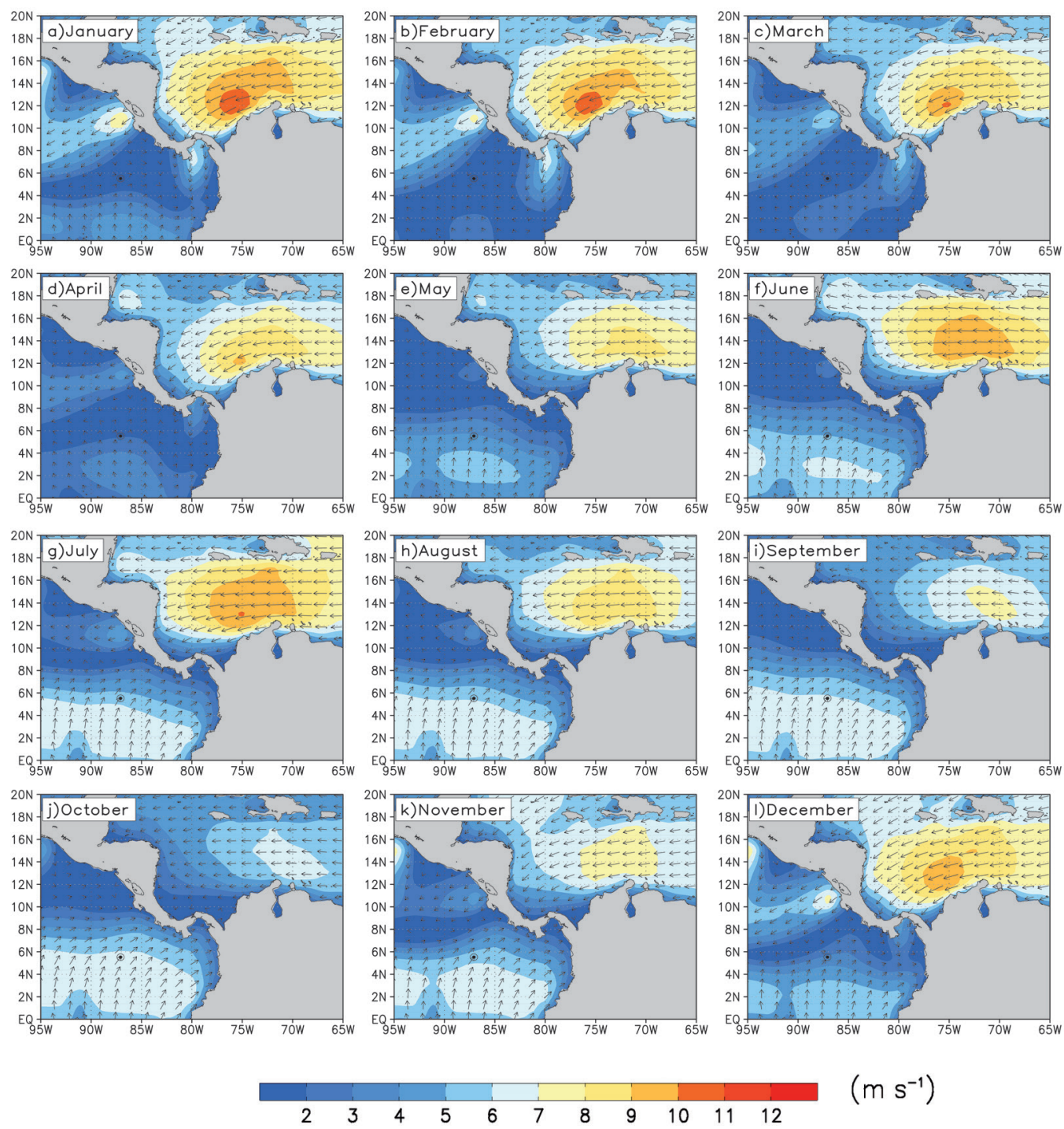

Fig. 9. Monthly climatology of wind at $10 \mathrm{~m}\left(\mathrm{~m} \mathrm{~s}^{-1}\right)$.

of precipitation is a common feature of both systems (SAMS and NAMS). The dynamics underlying the onset of the NAMS and the SAMS is an important ongoing subject of study. Field campaigns, as mentioned in Amador et al. (2016), have been implemented to improve the knowledge on the dynamics of these systems. A review of progress in the understanding of the AMS and future challenges were discussed by Vera et al. (2006). Disruptions in the AMS may have repercussions for the ETP and Caribbean weather and climate as proposed by Amador (2008), in regard to their relation with the CLLJ. According to Amador (2008) the CLLJ is the response of the largescale circulation to monsoons as ocean-land latitudinal thermal structures.

\section{The trades}

Trade winds owe their origin to the northsouth temperature gradient between the poles 
and the Equator. As the Earth rotates, the winds turn to the right and to the left, reacting to the Coriolis force in the $\mathrm{NH}$ and $\mathrm{SH}$, respectively. Figure 9 presents the monthly distribution of the wind vector over the ETP and CS. Trades are observed as north-easterlies in the CS and as south-westerlies in the southern portion of the ETP, once they cross the Equator. A seasonal change in wind speed (e.g., boreal winter and boreal summer) is one of the most relevant features of the IAS, linking the CS and ETP basins during much of the year (Figs. 9a to d).

\subsubsection{The Caribbean or the Intra-Americas Low-Level Jet}

Moisture transport by the CLLJ from the Caribbean to Central America and the central US is not only of scientific relevance, but also of great economic value to social welfare.

The National Center for Environmental Prediction/National Center for Atmospheric Research Reanalysis (NCEP/NCAR, Kalnay et al., 1996), North America Regional Reanalysis (NARR, Mesinger et al., 2006), European Reanalysis (ERA-40, Uppala et al., 2005) and ERA-Interim (Dee et al., 2011) data show CLLJ mean wind maxima of about $12-14 \mathrm{~m}$ $\mathrm{s}^{-1}$ near $925 \mathrm{hPa}$, or approximately $800 \mathrm{~m}$.a.s.1. (Amador, 1998; Muñoz, Busalacchi, Nigam, \& Ruiz-Barradas, 2008; Durán-Quesada et al., 2010; Serra et al., 2010). Amador (1998) reported the presence of a structure characterized by intensified trades with a core located approximately at $75^{\circ}-70^{\circ} \mathrm{W}$ between $12^{\circ}-15^{\circ}$ $\mathrm{N}$, at the $925 \mathrm{hPa}$ level during boreal summer. Amador (1998) also presented evidence that the structure was barotropically unstable and suggested that it was not related to local SST gradients (Fig. 5). Magaña et al. (1999) proposed this low-level jet structure to be implicated in the seasonal distribution of precipitation over Central America and Mexico. Recent publications have been focused on the structure and importance of the CLLJ for regional climate, as is discussed below. The lower levels are found to present the strongest westward winds over the Caribbean. The zonal wind field in Figure 9 shows the presence of this low level jet structure during boreal summer (Amador, 1998) and boreal winter (Amador et al., 2003), the latter for an extended data period. The CLLJ does not have a single temporal peak but two, it usually reaches the highest wind speeds in July but a secondary peak of intensity occurs in February (Amador et al., 2003; Amador, \& Mo, 2005; Amador et al., 2006; Wang, 2007). Figures $9 \mathrm{a}$ and g, for January and July, respectively, show a difference in CLLJ $10 \mathrm{~m}$ wind strength below the jet core, being stronger that of January. Although the reason is not clear, it may just respond to different methods in the reanalysis data. Note that the equinox seasons have weaker winds than the solstice seasons (Figs. 9d and i; versus Figs. 9f and 1).

In recent years various research groups have focused attention on the study of this imperfectibly understood jet structure, mainly because of its importance as a regional modulator of climate. Wang (2007) found an association between the maximum intensity of the CLLJ during summer, a maximum of sea level pressure (SLP), the MSD and a minimum of cyclone-genesis in the Caribbean Sea. Vertical wind shear associated with the CLLJ is shown by Wang \& Lee (2007) to have an impact on the Atlantic hurricane activity, in agreement with earlier work by Amador \& Magaña (1999). Using an index to measure the intensity of the CLLJ, Wang (2007) studied the relation of the CLLJ with the SST and SLP fields, so that during winter the CLLJ is related to the strengthening of the North Atlantic Subtropical High (NASH) and the weakening of the wintertime Aleutian Low. That suggested largescale teleconnections through the $\mathrm{NH}$ winter polar vortex. Meanwhile during summer the increased (decreased) intensity of the CLLJ is due to positive (negative) SLP anomalies near the NAMS region. A strong (weak) CLLJ is associated with a weak (strong) summer monsoon perhaps thermally forced in the lowlatitudes by the WHWP modulating the CLLJ as a result of a Gill type dynamical response to heating anomalies (Magaña et al., 1999; Wang, Lee, \& Enfield, 2008). 
Regarding SST, the results of Wang (2007), indicate that warm (cool) anomalies of the Caribbean are related to weak (strong) CLLJ. Whyte, Taylor, Stephenson, \& Campbell (2008) showed the CLLJ variations to be the first empirical orthogonal function mode of the zonal wind during July (representing up to $40 \%$ of the variability). The authors focus their study on the SST gradients and propose the intensification of the CLLJ to be modulated by a Pacific (warm) to Atlantic (cool) SST gradient. Muñoz et al. (2008) analyzed the structure of the CLLJ during its peaks and describe the CLLJ as an aspect of the Bermuda High, with an intensity modulated by land-sea temperature and orographic influences, with the strengthening of the CLLJ during late spring being a result of the east-west gradient of diabatic heating between Central America and the Caribbean.

A detailed study on the hydrodynamics of the CLLJ was reported by Cook \& Vizy (2010), in which the authors consider the geopotential gradient to explain the seasonal cycle of the CLLJ. They pointed out that this gradient tightens in July due to the presence of the NASH and in February due to the heat low of northern SA as proposed by Amador (2008). Largescale circulation patterns of the $\mathrm{NH}$ summer and winter CLLJ components suggested that they respond to land-ocean thermal contrasts during the summer season of each continent. Amador (2008) also argued that the CLLJ is a natural component of the American monsoons as a result of the continent's approximate northsouth land distribution. According to Cook \& Vizy (2010) the minimum of the CLLJ during October is a result of the increase of SST, and "a well-developed atmospheric boundary layer that mixes heat vertically and weakens the 925hPa meridional height gradients".

Wang (2007) analyzes the CLLJ variability and its relation to climate, and finds (as hypothesized by Magaña et al., 1999) a relation between the CLLJ and the MSD. The CLLJ also contributes to the generation of orographic precipitation (Amador et al., 2003; Muñoz et al., 2008; Amador, 2008; Cook, \& Vizy, 2010).
At the same time, according to Amador (2008), it enhances the eastward low-level divergence (convergence) of the moisture flux, causing a minimum (maximum) of precipitation over the central Caribbean (western Caribbean).

The level of the maximum winds determines to a great extent, in regions of lowlevel jets, the atmospheric mixed layer height (MLH) and the availability of moisture in the boundary layer. The MLH may be crucial, in the case of the CLLJ, to better understand large-scale moisture transport variability on synoptic and intraseasonal scales to Central America (Durán-Quesada et al., 2010), the GM (Mestas-Núñez et al., 2007) and the central US (Higgins et al., 1997). Precipitation variability also depends on the CLLJ multiscale interaction with other atmospheric global scale systems such as ENSO (Amador, 2008; Méndez, \& Magaña, 2010), the North Atlantic Oscillation (NAO, Mestas-Núñez et al., 2007), with easterly waves (Serra et al., 2010) and the GPLLJ (Mo et al., 2005).

Little is known in regard to the processes controlling the CLLJ. Processes associated with the SST meridional gradient have been proposed recently (Ranjha, Svensson, Tjernstrom, \& Semedo, 2013). However, according to Amador (2008) it is more likely that SST meridional gradient is associated with the CLLJ equatorward induced Ekman pumping. CLLJ induced upwelling due to strong surface winds cooled down the SST by $1-2^{\circ} \mathrm{C}$ during the summer Experimento Climático de Aguas Cálidas (ECAC) Phase 3 campaign of 2001 (Amador, 2008).

\subsubsection{The Chocó Jet}

During the NH fall season south-westerly winds from the $\mathrm{SH}$ extend across the equator into the tropics of the $\mathrm{NH}$ as the ITCZ displaces northward from its $\mathrm{NH}$ winter position. These winds from the Pacific Ocean are responsible for bringing moisture to Central America and western Colombia, especially during late spring to fall (Durán-Quesada et al., 2010). As discussed earlier, the wind as it crosses the 
Equator turns right due to the change of sign of the Coriolis force (see monthly wind values in Fig. 9) and to the local land-sea temperature gradient, among other factors (Hastenrath, 1991). The flow penetrates Colombia as a westerly low-level jet near $5^{\circ} \mathrm{N}$. Poveda \& Mesa (2000) described this jet as attaining its maximum values of 6-8 $\mathrm{m} \mathrm{s}^{-1}$ near $925 \mathrm{hPa}$, during October-November (not clearly shown in Figs. $9 \mathrm{j}$ and $\mathrm{k}$ since the $\mathrm{CJ}$ maximum is almost overland). The CJ brings enough moisture to the Chocó region, making it one of the rainiest sites in the world (Poveda, \& Mesa, 2000). The relationship of the CLLJ and CJ with ENSO is completely opposite. During warm (cold) ENSO phases the CLLJ shows stronger (weaker) than normal wind speeds during boreal summer (Amador et al., 2003; Amador, 2008), whereas the CJ presents the opposite behavior (Poveda, \& Mesa, 2000). The importance of the relationship of the CJ with ENSO forcing goes beyond current climate conditions. The convective cells linked with the CJ have been used to explain the advance of moraines in the Central Cordillera of Colombia, as well as the increase of moisture that western Colombia experienced during the last glaciation (Martínez, Keigwin, Barrows, Yokohama, \& Southon, 2003). Complementary to the explanation of the CJ dynamics relying on the meridional SST gradients and the cross-equatorial flow, it can also be added that anticyclonic vorticity is advected across the Equator by the divergent wind that results from the cross-equatorial temperature-pressure gradient. Zuluaga \& Poveda (2004) and Poveda et al. (2005) have indicated that latent heat release, due to large amounts of condensation and rainfall linked with mesoscale convective systems, enhance the strengthening of the CJ.

\subsubsection{Trans-isthmic jets}

In certain regions of Central America and Mexico, gaps in the topography allow the easterlies from the Caribbean to penetrate the mountains passes and reach the Pacific (Umatami, \& Yamagata, 1991; Fiedler, 2002; Xie, Xu, Kessler, \& Nonaka, 2005). Strong winds coming from southern Mexico and Central America gaps, exceed $10 \mathrm{~m} \mathrm{~s}^{-1}$, and have been explained in the past as a product of the large pressure gradients between the GM, the CS and the ETP. Cold fronts from the NH have been proposed to push the high pressure southward, triggering the acceleration of winds through these gaps, generating the Tehuantepec, and sequentially the Papagayo and Panama jets southward. However, Chelton, Freilich \& Esbensen (2000) performed a statistical analysis to study the link between those pressure gradients and the trans-isthmic jets (TJs). They found a poor correlation between variations in intensity of the Papagayo and Panama jets with the Tehuantepec Jet (see Fig. 1 of Amador et al., 2016), although the first two jets were significantly correlated with each other. The authors explain that the Tehuantepec Jet is driven by the across-gap pressure gradient, whereas the Papagayo and Panama Jets are driven by large-scale variations of the trade winds.

As described in section 2.3.2, the CLLJ reaches its maximum speed during the summer months of the $\mathrm{NH}$, and a secondary maximum during the winter months. When this strong current reaches the Caribbean coast of Costa Rica and Nicaragua, the mountains block part of it, but the semi-flat topography in the northern part of Costa Rica, allows this current to go through the continent and generate a jet on the Pacific coast, the Papagayo Jet. The strongest values are observed, however, during winter (Figs. 9a, b, 1). MAM are months where this jet is observed but with a weaker speed. During the NH summer, when the CLLJ strengthens, the Papagayo Jet is also observed, but as in the previous case, its values are low as estimated by the data used. In contrast to this, the Pan American Climate Studies Sounding Network (PACS-SONET) data shows a vigorous Papagayo Jet associated with the CLLJ during select summers (Amador, 2008).

Like the CLLJ, the Tehuantepec Jet is related to the strengthening and displacement of the NASH, displaying stronger speeds during October and through the winter. This jet 
is not shown completely here, it is just barely seen in the top left corner of Figures $9 a, b$ and c. Like the Papagayo Jet, the Tehuantepec Jet also shows a secondary maximum during July-August. According to Xie et al. (2005) and Romero-Centeno, Zavala-Hidalgo \& Raga (2006), this behavior could be related to the MSD, as the Papagayo Jet is not only restricted to the coast but extends as far as $2200 \mathrm{~km}$ offshore, inhibiting the northward penetration of low-level moisture transported by the southerly trade winds. During September, the TJs are weak, hence the moisture transport is stronger and the precipitation increases along the Pacific coast of Central America.

Another Central American mountain gap barely known or studied is the Gulf of Fonseca pass, between Nicaragua, Honduras and El Salvador (see Fig. 1 of Amador et al., 2016). This is due, perhaps, to the lack of highresolution oceanic and atmospheric data in that region (a jet-like horizontal structure is scantily observed in Figs. 9a and g when the CLLJ has a maximum in July-August). The
Panama mountain gap allows a southward jet to form during the winter months (Figs. 9a to c), presumably associated with the equatorial flank of the CLLJ and the southernmost position of the NASH. The Panama Jet disappears after April, while the other jets stay active but weaken until September, when the Papagayo Jet reduces to a minimum almost in phase with the CLLJ.

In the previously mentioned studies about gap flows, it has been shown that the ITCZ and the jets interact, with the strong jets inhibiting precipitation when the ITCZ migrates close to them. Chelton et al. (2000) showed how the Tehuantepec and Panama jets turn anticyclonically toward the west, which is consistent with jets that are inertially balanced at the coast and become more geostrophically balanced with distance away from the coast. The Papagayo Jet does not have this anticyclonic turn, which led the above authors to suggest that the winds are geostrophically balanced through the Papagayo gap.

Sidebar 1: Atmospheric rivers and their connection with the Caribbean Sea, the eastern tropical Pacific, and midlatitudes- E. Rivera

In Sections 2.1 and 2.2, the role of the ETP and the CS as sources of moisture for Central America and the IAS region, as a whole, was discussed. During the boreal winter, water vapor originated from those oceanic regions can also be transported into western North America through episodic structures, known as atmospheric rivers (ARs), and released as precipitation.

Filamentary structures of enhanced water vapor transport that originate in the tropics and subtropics are known as atmospheric rivers. ARs are major contributors to the annual precipitation in the western portions of mid-latitude continental regions (Ralph et al., 2006; Neiman, Ralph, Wick, Lundquist, \& Dettinger, 2008; Stohl, Forster, \& Sodemann, 2008; Roberge, Gyakum, \& Atallah, 2009; Neiman, Schick, Ralph, Hughes, \& Wick, 2011; Viale, \& Núñez, 2011; Lavers, Villarini, Allan, Wood, \& Wade, 2012; Lavers, \& Villarini, 2013). ARs cover $10 \%$ of the globe at any given time and are responsible for about $90 \%$ of the moisture flux in the extra-tropical troposphere (Zhu, \& Newell, 1998). The term "pineapple express" is used to describe wintertime ARs that form near Hawaii (central Pacific) and make landfall along the west coast and some portions of the interior southwest of the US. According to Ralph, Neiman \& Wick (2004), and Ralph, Neiman \& Rotunno (2005), these features are located in the warm sector of extra-tropical cyclones, ahead of the cold front, where a low-level jet is present. In the southwestern US, inland-penetrating ARs are also associated with cold season cutoff lows (Knippertz, \& Martin, 2007; Rivera, Domínguez, \& 
Castro, 2014) that bring moisture from the reservoir in the ETP. Figure S1 shows an AR that originated in the CS, passed to the ETP and impinged on the Baja California Peninsula in Mexico and parts of Arizona in the US on 30 November 2007. As observed, the maximum precipitable water content and moisture transport associated with this AR event exceeded $3 \mathrm{~cm}$ and $500 \mathrm{~kg} \mathrm{~m}^{-1} \mathrm{~s}^{-1}$, respectively.

On intraseasonal time scales, Ralph, Neiman, Kiladis, Weickmann \& Reynolds (2011) showed that changes in the tropical circulation across the Pacific Ocean, associated with the positioning of the convective phase of the MJO (briefly described below) allowed the propagation of an extra-tropical wave packet into the central tropical Pacific. This favored the formation of an intense AR, rooted in the tropics, which produced heavy precipitation and flooding in the US Pacific Northwest during March 2005. Guan, Waliser, Molotch, Fetzer \& Neiman (2012) determined that AR activity and snow accumulations in the Sierra Nevada are enhanced when MJO convection is located in the far western Pacific. On the other hand, Bao, Michelson, Nieman, Ralph \& Wilczak (2006) hypothesize that direct AR-related poleward transport of moisture from the ETP presents an interannual variability associated with ENSO due to changes in the intensity of the descending branch of the meridional Hadley circulation. The authors suggest that ARs connected with this tropical oceanic region are more (less) likely to occur in neutral (warm) phases of ENSO. Nonetheless, quantification of AR precipitation over western North America that originated in the ETP and the CS, as well as the modulation of AR activity and intensity by the MJO, ENSO and other low-frequency modes of variability are still subjects of study.
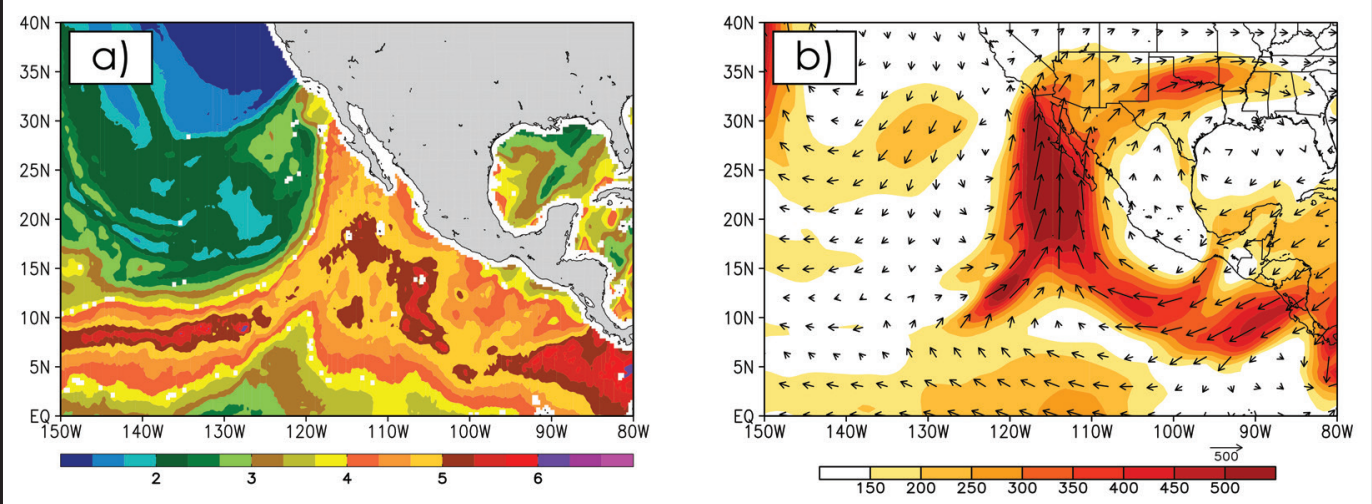

Fig. S1. (a) SSM/I precipitable water $(\mathrm{cm})$ and (b) ERA-Interim vertically-integrated water vapor transport $\left(\mathrm{kg} \mathrm{m}^{-1}\right.$ $\mathrm{s}^{-1}$; color shadings with vectors superimposed) fields associated with an AR rooted in the eastern tropical Pacific that impinged the Baja Peninsula in Mexico and portions of the Southwestern United States during 30 November 2007.

\subsection{Wind stress curl}

The wind stress strength helps the upper layers of the ocean achieve certain speed in the same direction as the wind, but the Coriolis force, due to the Earth's rotation, causes these currents to turn to the right in the NH. This process can lead to the known Ekman transport that can be interpreted as a balance of the wind stress and Coriolis forces. Thus, the curl of the wind stress force provides an idea of the rotation that a vertical column of air would experience in a varying wind field (Kessler, 2006). Positive (negative) wind stress curl causes divergence (convergence) in the Ekman layer and upward (downward) Ekman pumping (upwelling and downwelling, respectively). In the areas of strong low-level wind currents 

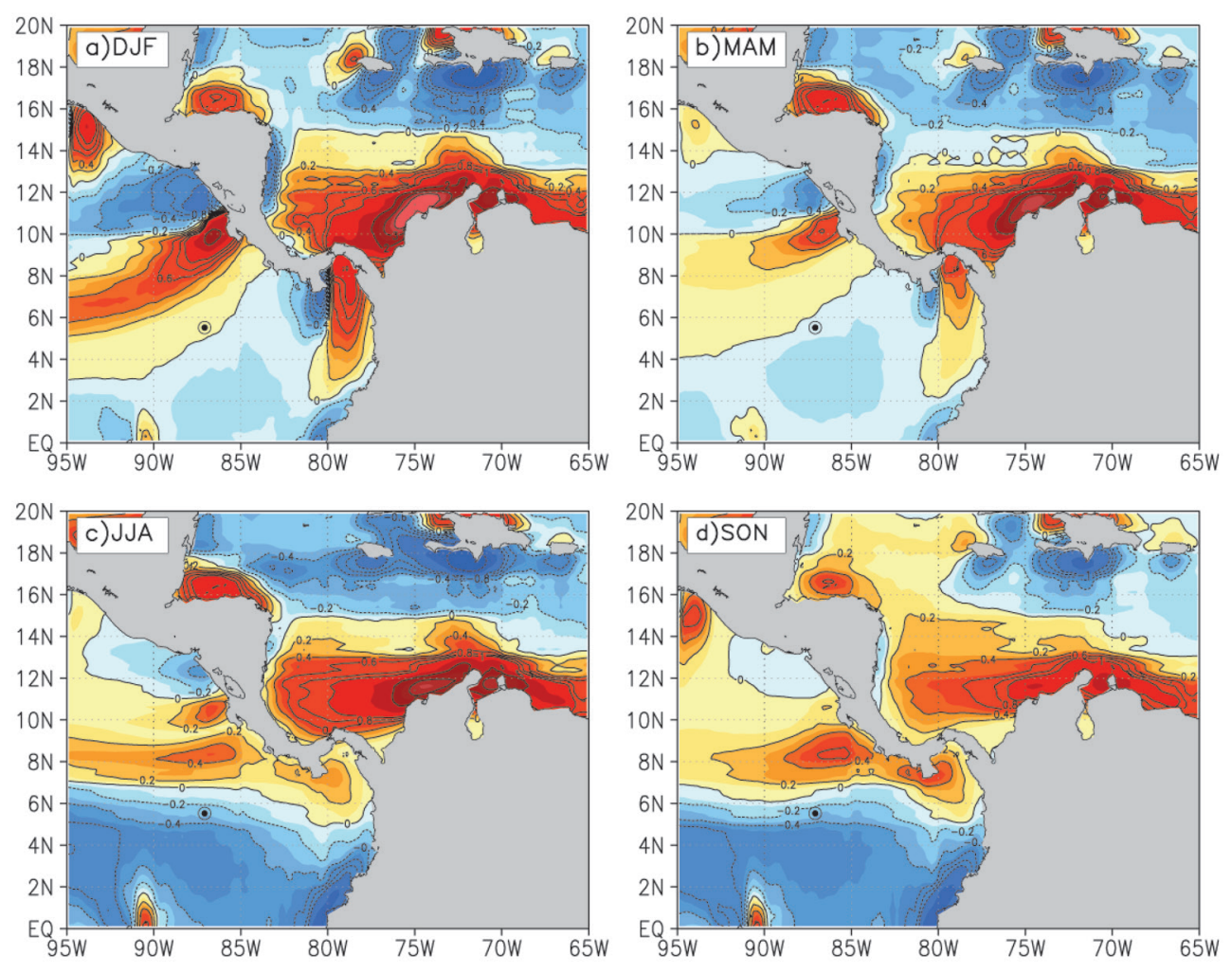

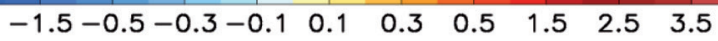

\section{$\left(10^{-7} \mathrm{~N} \mathrm{~m}^{-3}\right)$}

Fig. 10. Seasonal distribution of wind stress curl $\left(10^{-7} \mathrm{~N} \mathrm{~m}^{-3}\right)$ for (a) December-January-February (DJF), (b) March-AprilMay (MAM), (c) June-July-August (JJA) and (d) September-October-November (SON).

(jets), patterns of upwelling and downwelling are expected on both sides of the jet, depending on their spatial orientation, benefiting biological processes in the ocean, as is the case for the Costa Rica Dome (Fiedler, 2002; Cronin et al., 2002; Xie et al., 2005). Figures 10a to d show the seasonal wind stress curl computed with CCMP data. Positive wind stress curl (upwelling) can be found mostly during fall and winter near the Tehuantepec Jet, specifically to its right exit, whereas negative wind stress curl (downwelling) is usually found to its left exit. The same pattern is observed during winter and spring in the area of the Panama Jet and the Papagayo Jet. For the CLLJ, that dipolar behavior of the wind stress curl is present most of the year in the CS with strong upwelling north of Colombia and downwelling just south of Cuba. The wind stress curl shows the position and migration of the ITCZ throughout the year, identifiable as an area of positive wind stress curl values that displaces to its northernmost position during summer and its southernmost during winter, when the upwelling is stronger than in summer due to the stronger northerly winds during this season.

\subsection{Ocean eddies}

Ocean eddies are important not only for climate and ocean modeling, but for their effect on ocean biology. Gruber et al. (2011) 
confirmed a proposed hypothesis with regard to eddy generation and propagation. Eddies can affect biological productivity of nutrient-rich areas, being just unstable ocean currents of $10-100 \mathrm{~km}$ in length. According to Mahadevan (2014) eddies affect "the primary productivity of the regions, the fate of particulate organic carbon produced by photosynthesis and the regions' biogeochemical budgets". Since the TJs are prone to generate eddies in the Pacific waters of Central America (upwelling areas), the Costa Rica Dome may suffer important productivity changes throughout the seasons. Since there is a great deal of intraseasonal variability in the Papagayo Jet, it will be important to assess its effects on the productivity associated with the Costa Rica Dome.

Regional winds may result in strong upwelling along the Pacific coast of Central America and the study of this wind-upwelling link goes back to the early 20th Century (see for example, Hurd, 1929). The pioneer studies focused on the winter months in which the "Northers" (Roden, 1961) are more frequent and frontal incursions are a maximum. With the availability of satellite observations, the study of air-sea interaction processes related to the upwelling in the ETP region found a new perspective. However, the observed winter upwelling associated with the winds through the topographic gaps was not linked to the presence of strong eddies until the 1980s. As stressed in section 2.3.4, topographic gaps are present across the Isthmus of Tehuantepec and Panama, across Honduras ending at the Gulf of Fonseca and across Costa Rica ending at the Gulf of Papagayo. The overview of the wind field (Fig. 9) shows that low level winds funnel through these gaps, mostly during the winter months, exerting a stress force over the surface waters of the ETP. The first satellite detection of mesoscale eddies west of Papagayo and Tehuantepec was provided by Stumpf (1975) and it was not until the late 1980s that the community became interested in formally studying these ocean structures.

Clarke (1988) and Umatani \& Yamagata (1991), among others, used modeling to explain the physical mechanisms for the ocean eddies. The association between Ekman pumping and the wind stress curl has also been used to explain the generation of eddies (e.g., Crépon, \& Richez, 1982). Later studies such as that of Clarke (1988) explained the generation of the westward propagating anti-cyclonic eddies as an air-sea interaction process, reasoning that waters move southward due to the forcing of the low level winds.

Using a shallow water model, Umatani \& Yamagata (1991) found that some characteristics of the eddies are: a) a westward propagation that exceeds the long Rossby wave speed, b) a propagation speed associated with upper-layer thickness anomalies, c) a dynamical balance with the planetary wave dispersion and the non-linear planetary geostrophic divergence associated with order-one layer thickness changes, and d) a temperature dependent life cycle. Umatani \& Yamagata (1991), as well as Zamudio, Leonardi, Meyers \& O’Brien (2001), showed that eddies can be generated even when the wind forcing is almost negligible. One question to consider is if the eddies can be obtained neglecting the wind forcing. And if so, what other mechanisms can be linked with the generation and evolution of eddies. Hansen \& Maul (1991), also considering the North Equatorial Counter Current, proposed that boundary friction in the Costa Rica Coastal Current may be responsible for anti-cyclonic vorticity linked instabilities. The observational evidence supports the idea that augmented oscillations in the Costa Rica Coastal Current due to increased shear flow can lead to the breaking of cyclonic and anti-cyclonic eddies (Zamudio et al., 2001). Ubelmann \& Fu (2011) analyzed the case of eddies formed during tropical instability wave events in which the generation of eddies is related to the stretching and tilting through the evolution of a complex density front. Therefore, the generation of eddies is normally associated with: a) transisthmic winds, b) instability of coastal currents, and c) vorticity conservation.

With the current ocean observation facilities (thermal images, surface height, and 
near-surface winds) and eddy-resolving numerical models, the problem of the propagating eddies can be studied from different perspectives. Here we present recent research results. A full review through 2006 is provided by Willett, Leben \& Lavín (2006). Using Lagrangian drifting buoys, local meteorological stations and Advanced Very High Resolution Radiometer (AVHRR) imagery, Ballestero \& Coen (2004) analyzed the generation and propagation of eddies in the Gulf of Papagayo. Their results agree with the previous findings, which suggest that the generation mechanisms are forcing by inertially rotating Papagayo winds and potential vorticity conservation in the Costa Rica Coastal Current. Palacios \& Bograd (2005) studied the inter-annual variability of the number and characteristics of eddies. Their findings suggest that the warm phase of ENSO enhances eddy activity due to an increase of winter cold surges. A similar result was reported by Zamudio et al. (2006) in a study based on a highresolution numerical ocean model. According to their report, the number and intensity of anticyclonic Gulf of Tehuantepec eddies increased during warm ENSO events. The authors also note that eddy variability is not only forced by wind variations, but also by free propagating baroclinic downwelling coastal trapped waves.

Adams et al. (2011) studied the observed depth of eddy-driven impacts using the HYbrid Coordinate Ocean Model (HYCOM). They found that these impacts can extend from the upper-ocean and main thermocline to deepsea benthic environments. This result is very important as the study suggests that deep eddies can play a role in the transport of biota, chemicals and hydrothermal vent-derived heat. Using the eddy detection and tracking method by Kurian, Colas, Capet, McWilliams \& Chelton (2011), Liang et al. (2012) determined that the main eddy generation mechanism is a combination of low-frequency wind and boundary forcing. According to their results, the above mechanism accounts for 68-80\% (62-90\%) of the mesoscale variability in the Tehuantepec (Papagayo) oceanic region. According to results by Chang et al. (2012), the propagation of sea surface height signals is mainly observed west of Tehuantepec and Papagayo. This is because wind is weaker over the Panama gap, so that only localized sea surface height response along the jet axis is detected. The study indicates that coastal Ekman pumping is the initial forcing of eddies and their growth is supported by dynamical instabilities of the mean flow. Eddies west of Tehuantepec (Papagayo) have a period of approximately 85 (50) days and wavelength of 660 (590) km. Recently, Velázquez-Muñoz, Martínez \& Durazo (2014) studied the ocean response of offshore wind stress events using a three dimensional model. Their results suggest that the continental shelf may prevent eddy formation in the eastern Gulf of Tehuantepec. Moreover, it was found that anti-cyclonic eddies are induced by the effect of winds where the water depth rapidly changes away from the coast.

\subsection{Precipitation and evaporation}

\section{Precipitation}

Physical processes explaining precipitation on scales from days to years in the IAS region depend on various factors. Among them, it is cited, the dynamics of the CLLJ on various time scales (Amador, 1998; Wang et al., 2006; Amador, 2008), the WHWP variability (Wang et al., 2006), the interaction of the SST with synoptic scale systems (Salinas, 2006; Méndez, \& Magaña, 2010; Serra, Kiladis, \& Hodges, 2010), the ITCZ-CLLJ interaction (Hidalgo, Durán-Quesada, Amador, \& Alfaro, 2015), ENSO-CLLJ interactions (Amador, 2008), and other global scale signals (Savijarvi, Niemela, \& Tisler, 2005; Amador, Alfaro, Lizano, \& Magaña, 2006).

The distribution of precipitation in the IAS is also determined by convective processes over the Caribbean, the seasonal migration of the ITCZ, the hurricane season, cold fronts and the MSD, among other systems. The IAS is sensitive to intense rainfall events and severe floods which affect the Caribbean islands and Central America. In general terms, the distribution of precipitation over this region is 

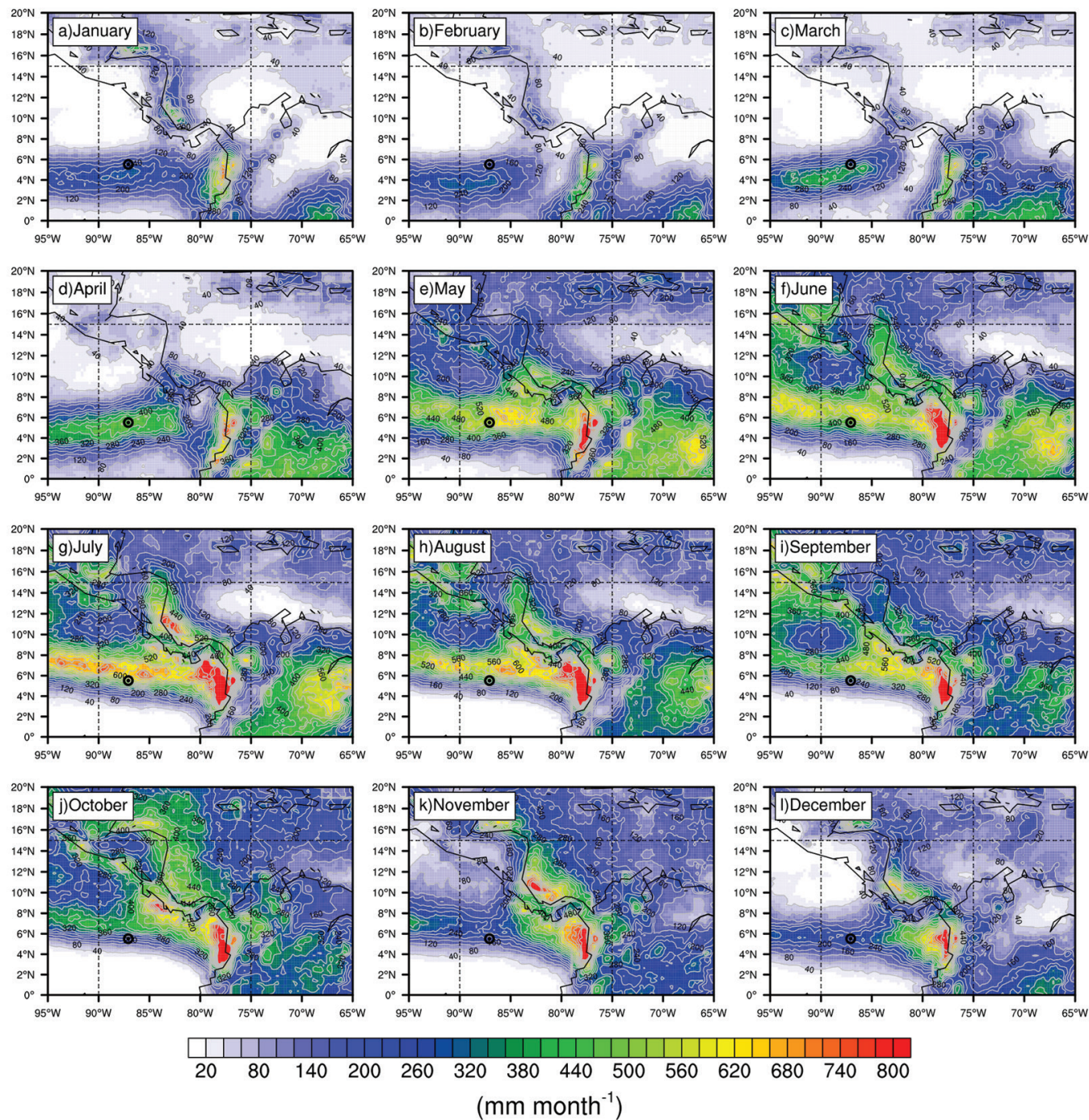

Fig. 11. Monthly climatology of precipitation $\left(\mathrm{mm} \mathrm{month} \mathrm{m}^{-1}\right)$.

bimodal. A significant reduction of precipitation during July-August is the main feature of the regional precipitation distribution, especially on the Pacific side. The climatology of monthly precipitation (Fig. 11) shows the presence of the ITCZ, as a well-determined band over the ETP. Maximum values of precipitation associated with the ITCZ depend on the season and region. The Panama Bight is a region with strong convection, leading to precipitation rates on the order of $20 \mathrm{~mm} \mathrm{day}^{-1}$. Precipitation along the Pacific slope is partly under the influence of the seasonal migration of the ITCZ (Fig. 11).

Portig (1965) and Hastenrath (1966) provide the earliest descriptions of the distribution of precipitation over Central America. Precipitation along the Caribbean slope is mainly triggered by the transport of moisture from the CS, local topography and cyclonic systems developing in the Atlantic (Amador et al., 2003). Central America has two rainfall maxima, one in May-June and one in September-October, with a marked dry spell in July-August. Winter 
and early spring are normally dry periods along the Pacific slope, as described by Alfaro (2002).

The dry period between the two rainfall maxima is the MSD (Fig. 4 of Magaña et al., 1999) and is just partially observed in Figs. 11f, $\mathrm{g}$ and $\mathrm{h}$, as a relative minimum of precipitation. The distribution of precipitation over Central America has also been found to be important to mean storm activity in the Eastern Pacific (Curtis, \& Gamble, 2008). The use of statistical and numerical modeling has also been used to study precipitation and its variability in the Caribbean for improving forecasting (Ashby, Taylor, \& Chen, 2005; Martínez-Castro et al., 2006; Curtis, \& Gamble, 2008). These studies reveal that important model biases exist in this region related primarily to the physical parametrizations used. Great efforts are being made to overcome these biases in model parameterizations (Biasutti, Sobel, \& Kushnir, 2006). The assimilation of observations is found to significantly reduce these biases in a recent NCEP Climate Forecast System Reanalysis dataset (Saha et al., 2010). Both the Pacific Ocean and CS contribute to the fluctuations observed in Caribbean rainfall rates (Chen, \& Taylor, 2002; Taylor, Enfield, \& Chen, 2002). A dry season in the Caribbean occurs during winter, followed by a sharp increase in precipitation after March. It is also important to remark that interannual variability in precipitation in the Caribbean is in part related to large-scale disturbances such as ENSO and the NAO, which also tend to affect the NASH (Amador, \& Magaña, 1999; Giannini, Kushnir, \& Cane, 2000; Mapes, Liu, \& Buenning, 2005).

\section{The Mid-Summer Drought}

The IAS shows complex annual and monthly patterns in the distribution of precipitation. Central America, as part of the IAS, is not an exception. One of these features, the MSD refers to a decrease in precipitation during July and August along the Central American Pacific coast. This region also presents a dry period during winter and early spring, followed by a peak in precipitation during June and another maximum in autumn. This MSD is popularly known as 'veranillo' and has been used by local farmers to determine the season for some agricultural crops. The MSD is a permanent feature of regional precipitation and is strongly related to low level winds and the NASH (Magaña et al., 1999; Wang, 2007). The link between the MSD and SST anomalies over warm water bodies is partially explained by variations in convective activity (Magaña et al., 1999). The MSD, as well as the intensification of the CLLJ as mentioned earlier, is also related to an intraseasonal strengthening and westward expansion of the NASH (Wang, 2007). The MSD is then associated with changes in convective activity linked to SST distribution, incoming solar radiation and the seasonal cycle of the easterly wind flow (Magaña et al., 1999). According to Wang (2007), the MSD is a large-scale phenomenon associated with both the NASH and the strength of the CLLJ. Karnauskas, Seager, Giannini \& Busalacchi (2013) based on the analyses of daily precipitation and diagnostic reanalysis fields proposed an extension of the work by Magaña et al. (1999). Karnauskas et al. (2013) argued that the MSD is related to the latitudinal dependence of the two climatological precipitation maxima to the biannual crossing of the solar declination angle.

In a recent paper, Hidalgo et al. (2015), linked precipitation patterns in the IAS with the CLLJ and the ITCZ, by proposing a dynamical mechanism that includes some physical processes in the CS and the ETP. Using data from the Global Precipitation Climatology Project (GPCP) covering Central America, the CS, the ETP and northern SA, four indexes that characterized the ITCZ were estimated: the latitudinal center of mass of precipitation (LA), the longitudinal center of mass of precipitation, the average precipitation in a region bounded by $10^{\circ} \mathrm{S}-25^{\circ} \mathrm{N}$ and $100^{\circ} \mathrm{W}-55^{\circ} \mathrm{W}$, and the spread of the precipitation patterns. A very strong correlation was found between summer LA and a summer index of the CLLJ. This suggested connections between Pacific and Caribbean climatic processes. The sign of the correlation implies that when the jet is stronger 
(weaker) there is a lower (higher) LA, and at the same time less (more) precipitation in the Pacific slope of Central America. The connection between the CS and ETP climate is not only related to low or high-level wind convergence, but to local convection in the western CS and the establishment of an upper zonal circulation that may be playing a role in the process. This circulation seems to be consistent during years when LA is lower than normal, apparently reinforcing the jet, and presents weaker strength during years of high LA. In addition to these processes, during warm (cold) ENSO events, the CLLJ is stronger (weaker) than normal at $925 \mathrm{hPa}$ (Amador, 2008), so the displacement of the ITCZ southward is more (less) severe.

Maximum values of evaporation are observed over the Caribbean (Fig. 12), Gulf of Mexico and tropical Atlantic with a maximum along the Gulf Stream (not shown), whereas minimum values are noticed along an equatorial belt (Fig. 12). Evaporation increases for the Caribbean during spring and summer (Figs. $12 \mathrm{~d}$ to $\mathrm{h}$ ), decreasing as autumn develops. Compare the consistency between Figures 3 and 12 for different time scale averages.
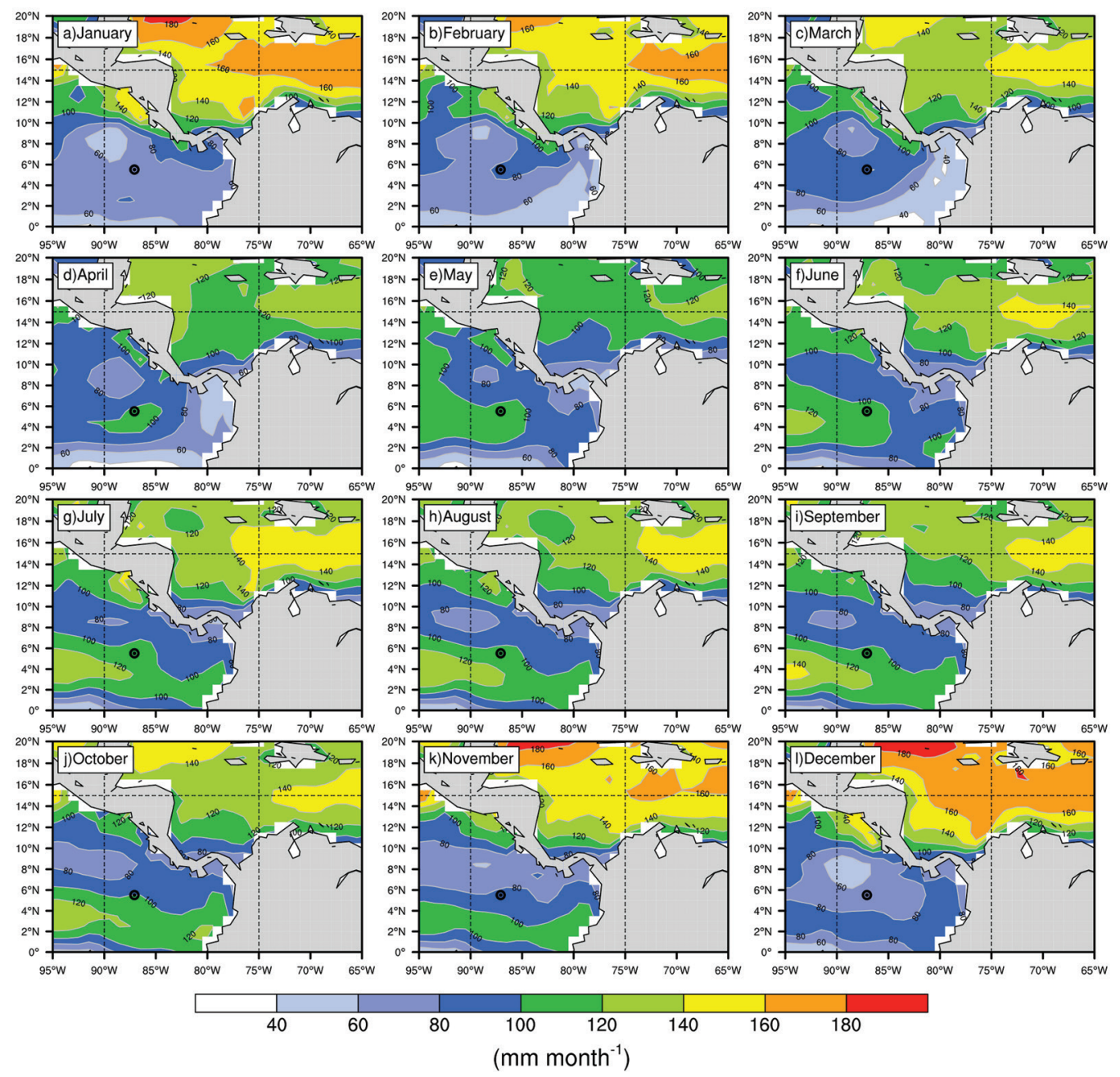

Fig. 12. Monthly climatology of evaporation $\left(\mathrm{mm} \mathrm{month}^{-1}\right)$. 


\section{Intraseasonal modes}

\subsection{High frequency oscillations}

Large synoptic and shorter (few hours and few tenths of $\mathrm{km}$ ) scale variability of near ocean surface parameters, SST, air temperature, pressure and specific humidity, were observed during the ECAC Phase 3 campaign for the period July 7-24, 2001, especially in the vicinity of the CLLJ core (Amador, 2008). Similarly, the atmospheric MLH showed considerable short and synoptic scale fluctuations (using in situ twice daily sounding observations) near and below the CLLJ core during this phase. A comparison of observed air temperature, specific humidity and wind profiles with those of NCEP-NCAR reanalysis, at grid points close to the observed sounding data, presented large differences in these parameters underestimating the actual atmospheric conditions (Amador, 2008). In this respect, there is a clear negative consequence to estimate the moisture availability and potential moisture transport with just reanalysis data. As expected, sensible heat and latent heat fluxes, and the wind stress also showed large synoptic and shorter scale variability (Amador, 2008), characteristics that are not captured by reanalysis data.

During warm (cold) ENSO phases, winds associated with the CLLJ core are stronger (weaker) than normal, so precipitation anomalies are positive (negative) in the western Caribbean near Central America and negative (positive) in the central IAS (Amador, 2008). Global scale signals such as AMO and PDO, together with changes in transient activity in the Caribbean (e.g., easterly waves, Serra et al., 2010) and changes in the intensity of the CLLJ have been suggested to have an important role in rainfall patterns (droughts) over Mexico (Méndez, \& Magaña, 2010). The variability of the CLLJ on synoptic and shorter time scales has not been fully studied. Therefore, its relationship with precipitation changes on those scales, and in the context of global scale signals such as ENSO, PDO, AMO, is practically unknown. This has, indeed, an adverse impact on regional medium and short-term weather forecasts, not only in the IAS region, but also in other regions such as the US Great Plains (Mo et al., 2005).

The possibility of the waves providing energy to the mean flow to maintain the CLLJ during summer also needs to be further explored (Salinas, 2006). Large-scale wave signatures, in relation to energy sources were studied in this region using reanalysis (Serra et al., 2010). It was found that some individual waves were maintained as they passed from the Atlantic into the east Pacific, whereas others were generated locally in the CS and the ETP. The tropospheric flow associated with the CLLJ over Central America shows a large synoptic and intraseasonal variability (Amador et al., 2006; Amador, 2008) when analyzed with PACS-SONET project data (Douglas, Fernández, \& Peña, 1999).

\subsection{Madden-Julian Oscillation}

The MJO (Madden, \& Julian, 1972) is the most important mode of intraseasonal variability in the tropical atmosphere. It is characterized by a convective envelope, associated with large-scale low and upper-level wind anomalies, that propagates eastward from the Indian Ocean at a speed of $5 \mathrm{~m} \mathrm{~s}^{-1}$ and has a periodicity of 30-90 days (Zhang, 2005). Following Wheeler \& Hendon (2004), the MJO cycle has been categorized into eight phases. Phases 1 and 8 correspond to MJO convection located in Africa and the Western Hemisphere, respectively. Phases 2-3 and 4-5 represent MJO convection over the Indian Ocean and adjacent ocean, respectively, and phases 6-7 relate to the propagation of the MJO convective signal through the western Pacific Ocean.

In the last decade, several studies have explored the relationship between the MJO and intraseasonal variability in the ETP, Central America and the Caribbean (e.g., Barlow, \& Salstein, 2006; Maloney, \& Esbensen, 2007; Barrett, \& Leslie, 2009; Klotzbach, 2010; Martin, \& Schumacher, 2011; Ventrice, Thorncroft, \& Roundy, 2011; Yu, Han, Maloney, Gochis, \& 
Xie, 2011; Crosbie, \& Serra, 2014; Klotzbach, \& Oliver, 2015). Barlow \& Salstein (2006) analyzed daily station data and determined that MJO activity in the ETP modulates the summertime precipitation on the Gulf of Mexico and the Pacific side of southern Mexico and Central America. In the most sensitive regions, the authors found that daily rainfall during the positive phase of the local MJO (enhanced convection) can be twice as large as that during the negative phase of the local MJO (suppressed convection). Using buoy and satellite observations for the boreal summers of 2000-2003, Maloney \& Esbensen (2007) showed that nearsurface westerly (easterly) wind anomalies at intraseasonal periods over the ETP warm pool occurred when convection is enhanced (suppressed) to the east of $120^{\circ} \mathrm{W}$. The periods of anomalous easterlies were associated with intensified activity of the Gulf of Tehuantepec and Gulf of Papagayo wind jets. Martin \& Schumacher (2011) examined satellite precipitation estimates and reanalysis winds in order to recognize a link between the MJO and the intraseasonal variability of precipitation in the CS region. They found that MJO modulation is strongest during SON. By considering the propagation phases of the MJO convection, as determined by Wheeler \& Hendon (2004), these authors identified positive precipitation anomalies of up to $50 \%$ with respect to the annual mean and decreased CLLJ intensity in phases 1 and 2 of the MJO. The opposite is true for phases 5 and 6 . The MJO influence on regional precipitation is still an open problem for tropical research. Magaña \& Caetano (2005) argued that the bimodal structure of precipitation over the Pacific side of Mesoamerica is not a form of intraseasonal variability in convective activity related to the MJO, but a characteristic of the annual cycle in precipitation.

Barrett \& Leslie (2009) suggest a physical relationship between the MJO and tropical cyclone activity in the Western Hemisphere. As the MJO propagates east of the dateline, its low-level signal vanishes and only the upperlevel signature remains present by the time it reaches the North Atlantic. If strong, this latter component produces large-scale upperlevel convergence (divergence) that favors (disfavors) tropical cyclone formation. Yu et al. (2011), however, show that surface signatures of the MJO propagate from the Indo-Pacific Ocean to the Atlantic through the Isthmus of Panama. Klotzbach (2010) studied the connection between the MJO phases and tropical cyclone frequency in the Atlantic basin over the 1974-2007 time period. The author found that the number of named tropical storms that formed in CS and the GM in phases 1 and 2 of the MJO is five times larger than in phases 6 and 7. According to Ventrice et al. (2011), the MJO directly modulates African easterly wave activity (AEW). During MJO phases 1 to 3 (6 to 8 ), AEW activity is locally enhanced (suppressed). In addition, phases 1 to 3 (7 and 8) are related to greatest (least) frequency of tropical cyclone formation in the Atlantic basin. This consistently follows the intraseasonal variations of AEW activity. Klotzbach \& Oliver (2015) obtained similar results to those of Klotzbach (2010) and Ventrice et al. (2011) when analyzing long-term records (from 1907 to 2011). Crosbie \& Serra (2014) performed regional model simulations of the boreal summers of 2002-2009 over the ENP and determined that the MJO mainly acts as a suppressor of tropical cyclogenesis during the suppressed phase and marginally favors tropical cyclone formation in the basin during the active phase.

\section{Monthly frequency of tropical cyclones}

The IAS is one of the most active regions in the world as far as the generation of tropical storms (TS) is concerned. The two components of the WHWP, the EPWP and the AWP, are energetically rich so that organized convection can lead to the development and intensification of disturbances. TS generated in the ETP often directly or indirectly impact the CS and vice versa (see Peña, \& Douglas, 2002 for mechanisms), and on occasion, these systems cross the continental region from the CS into the ETP. TS are the most deadly systems in the 
region for both the CS (with a large number of island states) and Central America. These systems also affect the economies of many countries in the region, some of them among the poorest in the Americas. For the latter region, see for instance, the work of Amador (2011) on socioeconomic impacts in Central America due to tropical storms during 2010.

TS are not only important on a seasonal basis. Scientists, including those from the social sciences, are exploring historical observations in order to determine if long-term behavior of TS frequency, intensity and paths is related to anthropogenic global warming. According to Lander \& Guard (1998) and Elsner \& Kocher (2000), no increase in global tropical cyclone frequency (TSF) has been demonstrated. Moreover, there is some disagreement amongst researches about TSF, some studies suggesting that future changes may be regionally-dependent (e.g., Sugi, Noda, \& Sato, 2002). The definition of TS intensity is another highly complicated issue since it depends on the metrics that are being used, such as average intensity, storm life, etc. Central America has been identified as a hot spot in the tropics for climate change (Giorgi, 2006). In this work, only the total number of named TS showed a significant trend at the $99 \%$ confidence limit in the CS according to the Mann-Kendall test (Amador et al., 2016).
In this section, the monthly behavior of TS is explored using only named TS in both basins for the period 1966 to 2014. A separation in TS status or categories was considered to determine which months present the maximum storm frequency per category. Figure 13 shows the monthly frequency distribution of TS (asterisks), hurricanes (pink bars) and strong hurricanes (red bars) for the ETP. Strong hurricanes are defined as those that reached category 3 or greater. As observed in this figure, September is the month with maximum total named TS, hurricanes and major hurricanes. Note that during this month and August, the historical number of hurricanes is about half of the named TS. August, however, behaves differently from July, which shows much less named TS but a comparable number of major hurricanes. Figure 14 presents the same data as Figure 13, except for the CS. Contrary to the ETP, the CS has its peak activity during August in all three classes, named TS, hurricanes and major hurricanes. Other months such as July and September also present a good degree of cyclone activity. The TS season appears to end smoothly during October in the CS, in contrast to the ETP, which shows a more abrupt end to TS and hurricane activity. June is a month that clearly contrasts the named TS number in the ETP with that of the CS. In both basins the TS season is restricted

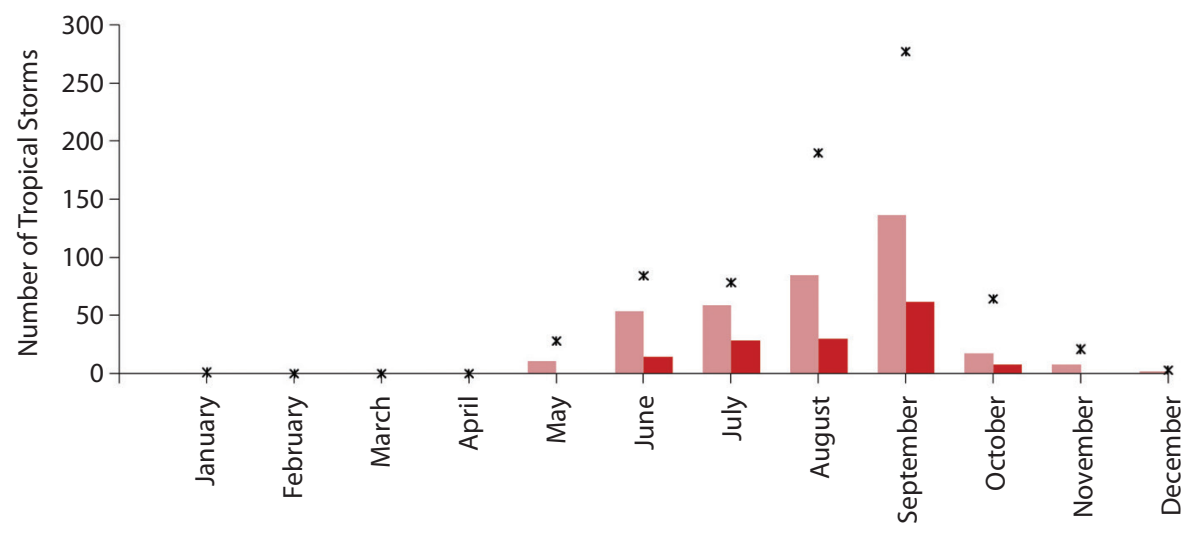

Month

Fig. 13. Mean monthly frequency of total named tropical storms (asterisks), hurricanes (light red) and major hurricanes (hurricane intensity reached or surpassed category 3 in red) over the eastern tropical Pacific from 1966 to 2014. 


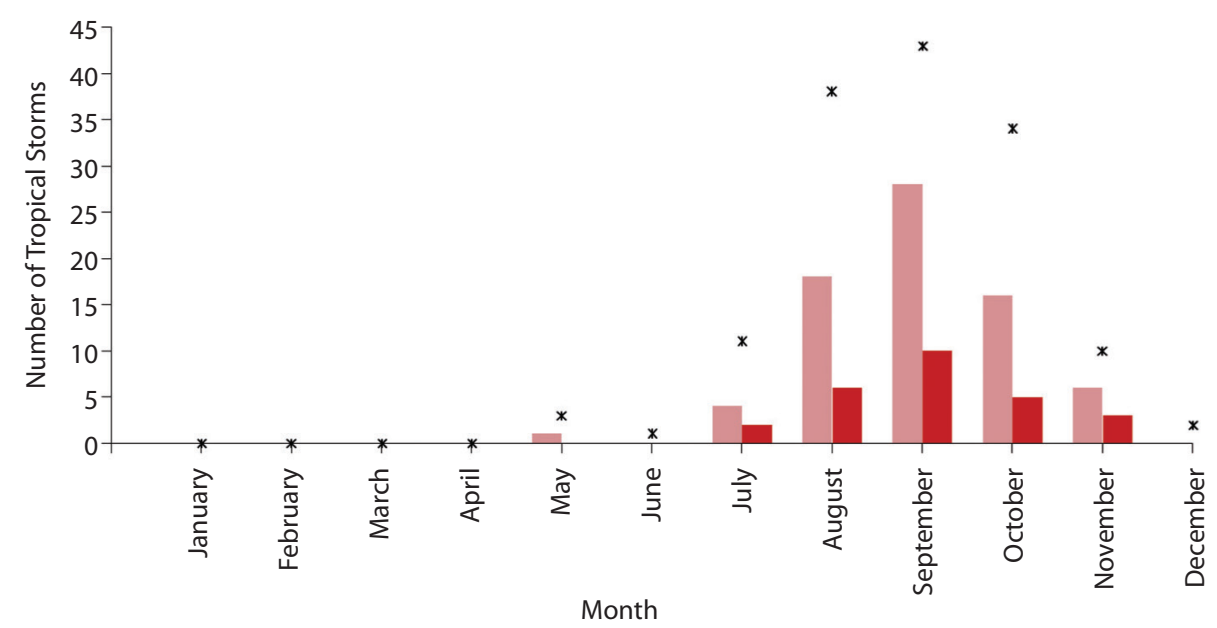

Fig. 14. Mean monthly frequency of total named tropical storms (asterisks), hurricanes (light red) and major hurricanes (hurricane intensity reached or surpassed category 3 in red) over the Caribbean Sea from 1966 to 2014.

to the period May-November, with very few cases in December.

\section{Summary and conclusions}

This work is Part II of a two-part review about climate and climate variability in some regions of the IAS, with emphasis on the CS and ETP. Both studies aimed at providing some basic material to oceanographers, marine biologists and other marine scientists on climate (Part I) and on ocean-atmosphere interaction processes on seasonal to intraseasonal time scales (Part II). High quality data from different sources were used, including information for the last decade (Section 1).

Incoming solar radiation and surface energy fluxes reveal, with good detail, the complex nature of the ETP and CS for convective activity and precipitation. The central CS and southeastern ETP are relevant regions that contribute to moisture transport and precipitation for Central America (Durán-Quesada et al., 2010). Using two different sets of SST data (OI and OAFlux), the nature and evolution of the WHWP were depicted. This study found some appreciable differences in the SST distribution between these databases, so caution is advised when using this information to define the
WHWP as in Wang \& Enfield (2001), or when estimating ocean-atmosphere energy budgets. The salinity field showed in general, as expected, a more saline CS than the ETP, however the northward migration of the ITCZ can have a significant impact on this field over the latter region due mainly to evaporation processes.

There is no doubt that the AMS influences the climate and climate variability of the ETP and CS, however, the precise way systems act to affect regional precipitation or transport of moisture to other regions are not clear. The AMS determines the strength of the meridional SLP, the intensity of the trades, and the continental distribution of surface temperature and precipitation. The NAMS and SAMS are both, characterized by intense low-level jets (GPLLJ and South America Low-Level Jet, respectively) transporting moisture to convective regions. The CLLJ, a natural mode of the AMS as proposed by Amador (2008), is known to act as a conveyor belt for moisture transport (Durán-Quesada et al., 2010). However, daily, intraseasonal and seasonal modes of the CLLJ and their interactions with other systems, such as tropical waves or cyclones, have not been fully investigated. In the context of the regional low-level jets, the CJ effect on moisture 
transport to Central America during autumn is also an important research topic.

Trans-isthmic jets, flow passing through the mountain gaps in Central America, have a relevant role in the transport of moisture to the ETP and exert a variable seasonal wind stress force over the ocean surface to cogenerate regions of great marine productivity, such as the Costa Rica Dome. One of the most prominent ocean-atmosphere processes in both basins is the effect of the force exerted on the ocean by the near surface wind. In a region with synoptic scale low-level jets (CLLJ, CJ), and several TJs, this effect is observed as regions of upwelling-downwelling and the generation of ocean gyres. The wind stress curl estimated from the CCMP data is consistent with the presence of the CLLJ and the TJs, and partially explain the generation of areas of great marine productivity in the region.

As part of the north-south processes interaction, ARs have become a topic of interest due to their prominent role in enhancing water vapor transport toward high latitudes (Knippertz, \& Martin, 2007; Rivera et al., 2014). In a Sidebar section, a study case was presented to show the structure of an AR and the moisture transport associated with it, in this case bringing water vapor from the CS to the ETP, and from there to higher latitudes.

Regional distribution of precipitation is due to a seasonal combination of factors. Among these factors are, isolated convection, the seasonal migration of the ITCZ, the hurricane season, the MSD, the seasonal and intraseasonal behavior of low-level jets and their interactions with transients, and the southward incursion of cold fronts. Many large-scale systems also contribute to the variability of precipitation in the region, such as ENSO, the $\mathrm{AMO}$ and the MJO, by modulating regional features associated with convection and precipitation. This diversity of systems and scales of motion have important implications for the ability of the scientific and operative communities to make predictions at different time horizons. In all the above processes the transport of moisture by the systems is crucial, however moisture is one of the least measured atmospheric fields in both basins.

Using data from the GPCP for Central America, the CS, the ETP and northern SA, Hidalgo et al. (2015) estimated four indices that characterized the ITCZ. One of them, the latitudinal center of mass of precipitation (LA) showed a very strong correlation between summer LA and a summer index of the CLLJ. This suggested connections between Pacific and Caribbean climatic processes. In that work a dynamical mechanism was proposed to explain the observed correlations.

Large synoptic and shorter scale variability of near ocean surface parameters, SST, air temperature, pressure and specific humidity were observed during the ECAC Phase 3 campaign for the period July 7-24, 2001, especially in the vicinity of the CLLJ core (Amador, 2008). This experiment showed a clear negative consequence of the actual observing networks in the region, since estimates of moisture availability and potential moisture transport with just reanalysis data may produce large errors. As expected, sensible heat and latent heat fluxes and the wind stress also showed large synoptic and shorter scale variability (Amador, 2008), characteristics that are not captured by current reanalysis products.

An important global mode that influences regional convection and precipitation is the MJO, however its effect on seasonal or intraseasonal precipitation variability is still an open problem for tropical research (e.g., Magaña, \& Caetano, 2005; Barlow, \& Salstein, 2006). Crosbie \& Serra (2014) used regional model simulations during the boreal summers of 2002-2009 over the ENP to determine that MJO mainly acts as a suppressor of tropical cyclogenesis during the suppressed phase and marginally favors tropical cyclone formation in the basin during the active phase.

Monthly TS activity in the CS and ETP basins is restricted to the period May-November, with very few cases in December. The CS presents TS peak activity during August, as well as for the number of hurricanes and major hurricanes, in contrast to the ETP that shows 
the same features during September. The end of the TS season is more abrupt in the ETP than in the CS, in other words, October in the ETP is a much less active period than SeptemberOctober for the CS.

The IAS is still an open laboratory for atmospheric research. This region holds many meteorological systems imperfectibly known in nature. The CLLJ interaction with easterly waves and other modes of intraseasonal variability and their effect on the generation of tropical cyclones and precipitation distribution is far from being a resolved problem. Some mechanisms modulating the MSD have been proposed, however, none of them has been tested with enough observed data. The importance of zonal and meridional moisture transport from this tropical area to other regions in the IAS and to mid-latitudes is beyond any doubt, however, better knowledge on the primary mechanisms involved in this advection is still missing. Most data used here come from reanalysis efforts of good quality generated at global centers for weather and climate. Unfortunately, the number of upper air observations in the IAS, fundamental to test reanalysis data, has not followed that effort at the same pace. Field experiments in the IAS devoted to acquire data at different time and space scales would be a remarkable improving factor to promote a better understanding of the physical and dynamical mechanisms involved in the weather and climate of the IAS.

\section{ACKNOWLEDGEMENTS}

The authors wish to acknowledge the support of the following projects: IAI-CRN2-050, UCR-VI-805-B0-065, A8-606, B0-130, A9-224, A7-002, B0-402, B3-600, B4-227, B5-296, B5-601 and 808-A9-180, and show their appreciation to four anonymous reviewers for helpful comments and suggestions. Special thanks to Brian Mapes for valuable comments and recommendations to improve the quality of this review. J.A.A. thanks Dr. Jorge Cortés, P.I. of the project "CONARE: Interacciones océano-atmósfera y la biodiversidad marina de la Isla del Coco, Costa Rica”, for the opportunity to collaborate in this research. Thanks also to Ingrid Rivera, Carla Vega, Carlos Bojorge, Paula Pérez and Xiannie Rivas for their extensive collaboration in the logistics of data and the elaboration of some of the figures for this paper. A.M.D.Q acknowledges Daiana García and Pedro Chaves for data retrieval during complimentary scholar assistantship service.

\section{RESUMEN}

La región oriental del Pacífico Tropical. Parte II: Modos atmosféricos de variabilidad estacional e intra-estacional: Esta es la Parte II de una revisión en dos partes del clima y la variabilidad climática, enfocada en el Pacífico Tropical del Este (PTE) y el Mar Caribe (MC). Ambas partes del trabajo tienen como objetivo proveer a oceanógrafos, biólogos marinos y otros científicos marinos, una guía base de las interacciones océano-atmósfera que afectan el PTE, el MC y las aguas de la Isla del Coco, Patrimonio de la Humanidad de Costa Rica. La Parte I analizó para el PTE y MC y para las región $25^{\circ} \mathrm{S}-35^{\circ} \mathrm{N}$, $20^{\circ} \mathrm{W}-130^{\circ} \mathrm{W}$, los campos medios anuales. En este trabajo el área de interés es $65^{\circ} \mathrm{W}-95^{\circ} \mathrm{W}, 0^{\circ}-20^{\circ} \mathrm{N}$, como complemento a la Parte I. La radiación solar y los flujos superficiales de energía muestran una compleja naturaleza del PTE y MC, en relación con la actividad convectiva y la precipitación en escalas de tiempo estacionales e intra-estacionales. Ambas regiones son importantes como fuentes de evaporación y para los procesos de transporte regional de humedad. El Sistema Monsónico de América (SMA) influencia el clima y variabilidad climática del PTE y CS, sin embargo, la forma precisa en que los sistemas actúan para afectar la precipitación regional y el transporte de humedad, en la región de los Mares Intra Americanos (MIA), no es clara. A pesar de que la Corriente en Chorro del Caribe (CCC) actúa como una cinta transportadora de humedad, los modos estacionales e intra-estacionales de la CCC y sus interacciones con otro sistemas en la región del MIA, tienen que ser aún investigados. Las corrientes transistmicas ejercen un variable esfuerzo estacional del viento sobre la superficie oceánica cogenerando regiones de gran productividad marina. Convección aislada, la migración estacional de la Zona de Convergencia Intertropical, la temporada de huracanes, el veranillo, el comportamiento estacional e intra-estacional de las corrientes de bajo nivel y su interacción con sistemas transitorios y la incursión en latitudes bajas de frentes fríos contribuyen a la precipitación estacional en la región. Muchos sistemas de gran escala, como el Niño-Oscilación del Sur, la Oscilación Multidecenal del Atlántico y la Oscilación de MaddenJulian contribuyen también a la variabilidad de la precipitación, al modular características regionales asociadas a la convección y la precipitación. La actividad mensual de 
tormentas tropicales (TT) se restringe en el PTE y MC al periodo mayo-noviembre, con muy pocos casos en diciembre. El MC presenta picos de TT durante agosto, lo mismo que el número de huracanes y el de huracanes fuertes, en contraste con el PTE que muestra estas características durante septiembre. El final de la temporada de TT es más abrupta en el PTE que en el MC, en donde octubre es un periodo menos activo que septiembre-octubre en el MC.

Palabras clave: Isla del Coco, modos de variabilidad climática estacional e intra-estacional, Oscilación de Madden-Julian, Corriente en Chorro de Bajo Nivel del Caribe, Chorro del Chocó, corrientes trans-ístmicos, ríos atmosféricos.

\section{REFERENCES}

Adams, D. K., \& Comrie, A. C. (1997). The North American Monsoon. Bulletin of American Meteorological Society, 78, 2197-2213.

Adams, D. K., McGillicuddy, D. J., Zamudio, L., Thurnherr, A. M., Liang, X., Rouxel, O., \& Mullineaux, L. S. (2011). Surface-generated mesoscale eddies transport deep-sea products from hydrothermal vents. Science, 332(6029), 580-583.

Alfaro, E. J. (2002). Some characteristics of the annual precipitation cycle in Central America and their relationships with its surrounding tropical oceans. Tópicos Meteorológicos y Oceanográficos, 9, 88-103.

Alfaro, E. J., \& Cortés, J. (2012). Atmospheric forcing of cold subsurface water events in Bahía Culebra, Costa Rica. Revista de Biología Tropical, 60(Supplement 2), 173-186.

Allen, G. R. (2008), Conservation hotspots of biodiversity and endemism for Indo-Pacific coral reef fishes. Aquatic Conservation: Marine and Freshwater Ecosystems, 18, 541-556. doi: 10.1002/aqc. 880

Amador, J. A. (1998). A climatic feature of the tropical Americas. The trade wind easterly jet. Tópicos Meteorológicos y Oceanográficos, 5(2), 91-102.

Amador, J. A. (2008). The Intra-Americas Seas Low-Level Jet (IALLJ): Overview and Future Research. Annals of the New York Academy of Sciences, 1146(1), 153188. doi:10.1196-annals.1446.012.

Amador, J. A., 2011. Socio-economic impacts associated with meteorological systems and tropical cyclones in Central América in 2010. Bulletin of the American Meteorological Society, 92(6), S184.

Amador, J. A., \& Magaña, V. (1999, January). Dynamics of the low level jet over the Caribbean Sea. Preprints of the $23^{\text {rd }}$ Conference on Hurricanes and Tropical Meteorology, Dallas, Texas, USA.

Amador, J. A., \& Mo, K. C. (2005, October). The IntraAmericas Sea Low- Level Jet. Poster session presented at the $30^{\text {th }}$ Annual Climate Prediction Center, Pennsylvania, USA.

Amador, J. A., Chacón, J. R., \& Laporte, S. (2003). Climate and climate variability in the Arenal Basin of Costa Rica. In H. F. Díaz, \& B. Morehouse (Eds.), Climate and Water: Transboundary Challenges in the Americas (pp. 317-350). The Netherlands: Kluwer Academic Publishers.

Amador, J. A., Alfaro, E. J., Lizano, O. G., \& Magaña, V. O. (2006). Atmospheric forcing of the eastern tropical Pacific: A review. Progress in Oceanography, 69, 101-142.

Amador, J. A., Rivera, E. R., Durán-Quesada, A. M., Mora, G., Sáenz, F., Calderón, B., \& Mora, N. (2016). The easternmost tropical Pacific. Part I: A climate review. Revista de Biología Tropical, 64(Supplement 1), S1-S22.

Ashby, S. A., Taylor, M. A., \& Chen, A. A. (2005). Statistical models for predicting rainfall in the Caribbean. Theoretical and Applied Climatology, 82, 65-80.

Ballestero, D., \& Coen, J. E. (2004). Generation and propagation of anticyclonic rings in the Gulf of Papagayo. International Journal of Remote Sensing, 25(11), 2217-2224.

Bao, J. W., Michelson, S. A., Nieman, P. J., Ralph, F. M., \& Wilczak, J. M. (2006). Interpretation of enhanced integrated water vapor bands associated with extratropical cyclones: Their formation and connection to tropical moisture. Monthly Weather Review, 134, 1063-1080.

Barlow, M., \& Salstein, D. (2006). Summertime influence of the Madden-Julian Oscillation on daily rainfall over Mexico and Central America. Geophysical Research Letters, 33, L21708. doi: 10.1029/2006GL027738

Barrett, B. S., \& Leslie, L. M. (2009). Links between tropical cyclone activity and Madden-Julian oscillation phase in the North Atlantic and Northeast Pacific basins. Monthly Weather Review, 127, 727-744.

Biasutti, M., Sobel, A. H., \& Kushnir, Y. (2006). AGCM precipitation biases in the tropical Atlantic. Journal of Climate, 19, 935-958.

Bosilovich, M. G., Sud, Y. C., Schubert, S. D., \& Walker, G. K. (2003). Numerical simulation of the largescale North American Monsoon water sources. Journal of Geophysical Research, 108(9), 1- 14. doi: 10.1029/2002JD003095

Carton, J. A., \& Giese, B. S. (2008). A reanalysis of ocean climate using Simple Ocean Data Assimilation (SODA). Monthly Weather Review, 136, 2999-3017.

Castro, C. L., McKee, T. B., \& Pielke, R. A. (2001). The relationship of the North American monsoon to tropical and North Pacific sea surface temperatures as revealed by observational analyses. Journal of Climate, 14, 4449-4473. 
Chang, C-H., Xie, S-P., Schneider, N., Qiu, B., Small, J., Zhuang, W., Taguchi, B., Sasaki, H., \& Lin, X. (2012). East Pacific ocean eddies and their relationship to subseasonal variability in Central American wind jets. Journal of Geophysical Research, 117. doi: 10.1029/2011JC007315

Chelton, D., Freilich, M., \& Esbensen, S. (2000). Satellite observations of the Wind Jets off the Pacific coast of Central America. Part II: Regional relationships and dynamical considerations. Monthly Weather Review, 128, 2019-2043.

Chen, A. A., \& Taylor, M. A. (2002). Investigating the link between early season Caribbean rainfall and the El Niño +1 year. International Journal of Climatology, $22,87-106$

Chen, S. J., Li, D. L., \& He, J. H. (2012). Influence of the Surface Sensible Heat Flux of North Asian Continent in Winter on Meiyu in Yangtze-Huaihe Valleys. Plateau Meteorology, 2, 008.

Clarke, A. J. (1988). Inertial wind path and sea surface temperature patterns near the Gulf of Tehuantepec and Gulf of Papagayo. Journal of Geophysical Research (Oceans), 93(C12), 15491-15501.

Cook, K. H., \& Vizy, E. K. (2010). Hydrodynamics of the Caribbean Low-Level Jet and its relationship to precipitation. Journal of Climate, 23, 1477-1494. doi: 10.1175/2009JCLI3210.1

Crépon, M., \& Richez, C. (1982). Transient upwelling generated by two-dimensional atmospheric forcing and variability in the coastline. Journal of Physical Oceanography, 12(12), 1437-1457.

Cronin, M. F., Bond, N., Fairall, C., Hare, J., McPhaden, M. J., \& Weller, R. A. (2002). Enhanced oceanic and atmospheric monitoring underway in Eastern Pacific. EOS, Transactions, 83(19), 205, 210-211.

Crosbie, E., \& Serra, Y. (2014). Intraseasonal modulation of synoptic-scale disturbances and tropical cyclone genesis in the Eastern North Pacific. Journal of Climate, 27, 5724-5745. doi: http://dx.doi.org/10.1175/ JCLI-D-13-00399.1

Curtis, S., \& Gamble, D. W. (2008). Regional variations of the Caribbean mid-summer drought. Theoretical and Applied Climatology, 94(1-2), 25-34.

Dee, D. P., Uppala, S. M., Simmons, A. J., Berrisford, P., Poli, P., Kobayashi, S., Andrae, U., Balmaseda, M. A., ... \& Vitart, F. (2011). The ERA-Interim reanalysis: configuration and performance of the data assimilation system. Quarterly Journal of the Royal Meteorological Society, 137, 553-597. doi:10.1002/ qj. 828

Douglas, M. W., Maddox, R. A., Howard, K., \& Reyes, S. (1993). The Mexican Monsoon. Journal of Climate, 6, 1665-1678.
Douglas, M., Fernández, W., \& Peña, M. (1999, January). Design and evolution of the PACS SONET observing system in Latin America. Paper presented at $3^{\text {rd }}$ Symposium on Integrated Observing Systems, Dallas, Texas, USA.

Durán-Quesada, A. M., Gimeno, L., Amador, J. A., \& Nieto, R. (2010). A Lagrangian approach to moisture sources for Central America: Part I. Moisture sources identification. Journal of Geophysical Research, 15. doi: 10.1029 / 2009JD012455.

Elsner, J. B., \& Kocher, B. (2000). Global tropical cyclone activity: A link to the North Atlantic Oscillation. Geophysical Research Letters, 27, 129-132.

Fiedler, P. (2002). The annual cycle and biological effects of the Costa Rica dome. Deep-Sea Research, 49, 321-338.

Fiedler, P. C., \& Talley, L. D. (2006). Hydrography of the eastern tropical Pacific: A review. Progress in Oceanography, 69, 143-180. doi:10.1016/j. pocean.2006.03.008

Fuller, R. D., \& Stensrud, D. J. (2000). The Relationship between Tropical Easterly Waves and Surges over the Gulf of California during the North American Monsoon. Monthly Weather Review, 128, 2983-2989.

Giannini, A., Kushnir, Y., \& Cane, M. A. (2000). Interannual variability of Caribbean rainfall, ENSO, and the Atlantic Ocean. Journal of Climate, 13, 297-311.

Gimeno, L., Drumond, A., Nieto, R., Trigo, R. M., \& Stohl, A. (2010). On the origin of continental precipitation. Geophysical Research Letters, 37, L13804. doi: 10.1029/2010GL043712

Gimeno, L., Nieto, R., Drumond, A., Durán-Quesada, A. M., Stohl, A., Sodemann, H., \& Trigo, R. M. (2011). A close look at oceanic sources of continental precipitation, Eos. Transactions American Geophysical Union, 92(23), 193. doi:10.1029/2011EO230001

Giorgi, F. (2006). Climate change hot-spots. Geophysics Research Letters, 33, 8707.

Gochis, D. J., Shuttleworth, W. J., \& Yang, Z. L. (2002). Sensitivity of the modeled North American monsoon regional climate to convective parameterization. Monthly Weather Review, 130, 1282-1298.

Gruber, N., Lachkar, Z., Frenzel, H., Marchesiello, P., Münnich, M., McWilliams, J., Nagai T., \& Plattner, G. (2011). Eddy-induced reduction of biological production in eastern boundary upwelling systems. Nature Geoscience, 4(11), 787-792. doi :10.1038/ ngeo1273

Guan, B., Waliser, D. E., Molotch, N. P., Fetzer, E. J., \& Neiman, P. J. (2012). Does the Madden-Julian oscillation influence wintertime atmospheric rivers and snowpack in the Sierra Nevada? Monthly Weather Review, 140, 325-342. 
Hansen, D. V., \& Maul, G. A. (1991). Anticyclonic current rings in the eastern tropical Pacific Ocean. Journal of Geophysical Research, 96, 6965-6979.

Hastenrath, S. (1966). On general circulation and energy budget in the area of the Central American seas. Journal of Atmospheric Sciences, 23, 694-711.

Hastenrath, S. (1991). Climate Dynamics of the Tropics. Dordrecht, Netherlands: Kluwer Academic Publishers.

Hidalgo, H. G., Durán-Quesada, A. M., Amador, J. A., \& Alfaro, E. (2015). The Caribbean Low-Level Jet, the Inter-Tropical Convergence Zone and precipitation patterns in the Intra-Americas Sea: A proposed dynamical mechanism. Geografiska Annaler, Series A, Physical Geography. Series A: Physical Geography, 97(1), 41-59. doi:10.1111/geoa.12085

Higgins, W., Ahijevych, D., Amador, J., Barros, A., Berbery, E.H., Caetano, E., Carbone, R., Ciesielski, P., ... \& Zhang, C. (2006). The NAME 2004 field campaign and modeling strategy. Bulletin American Meteorological Society, 87, 79-94. doi: http://dx.doi. org/10.1175/BAMS-87-1-79

Higgins, R. W., Yao, Y., \& Wang, X. L. (1997). Influence of the North American Monsoon System on the U.S. Summer precipitation regime. Journal of Climate, 10, 2600-2622.

Higgins, W., \& Gochis, D. (2007). Synthesis of results from the North American Monsoon Experiment (NAME) process study. Journal of Climate, 20, 1601-1607.

Hu, H., \& Dominguez, F. (2015). Evaluation of oceanic and terrestrial sources of Moisture for the North American Monsoon using numerical models and precipitation stable isotopes. Journal Hydrometeor, 16, 19-35.

Huffman, G. J., Adler, R. F., Bolvin, D. T., Gu, G. J., Nelkin, E. J., Bowman, K. P., Hong, Y., Stocker, E. F., \& Wolff, D. B. (2007). The TRMM multisatellite precipitation analysis (TMPA): Quasi-global, multiyear, combined-sensor precipitation estimates at fine scales. Journal of Hydrometeorology, 8, 38-55.

Hurd, W. E. (1929). Northers of the Gulf of Tehuantepec. Monthly Weather Review, 57, 192-194.

Kalnay, E., Kanamitsu, M., Kistler, R., Collins, W., Deaven, D., Gandin, L., Iredell, M., Saha, ... \& Joseph, D. (1996). The NCEP/NCAR 40-Year Reanalysis Project. Bulletin American Meteorological Society, 77, 437-471.

Karnauskas, K. B., Seager, R., Giannini, A., \& Busalacchi, A. J. (2013). A simple mechanism for the climatological midsummer drought along the Pacific coast of Central America. Atmósfera, 28, 261-281.

Kessler, W. (2006). The circulation of the eastern tropical Pacific: A review. Progress in Oceanography, 69, 181-217.
Klotzbach, P. J. (2010). On the Madden-Julian oscillationAtlantic hurricane relationship. Journal of Climate, 23, 282-293. doi:10.1175/2009JCLI2978.1

Klotzbach, P. J., \& Oliver, E. C. J. (2015). Modulation of Atlantic basin tropical cyclone activity by the Madden-Julian Oscillation (MJO) from 1905 to 2011. Journal of Climate, 28, 204-217. doi: http://dx.doi. org/10.1175/JCLI-D-14-00509.1

Knippertz, P., \& Martin, J. E. (2007). A Pacific moisture conveyor belt and its relationship to a significant precipitation event in the semiarid southwestern United States. Weather and Forecasting, 22, 125-144.

Kumar, B. P., Vialard, J., Lengaigne, M., Murty, V. S. N., \& McPhaden, M. J. (2012). TropFlux: Air-Sea Fluxes for the Global Tropical Oceans - Description and evaluation. Climate Dynamics, 38, 1521-1543.

Kurian, J., Colas, F., Capet, X., McWilliams, J. C., \& Chelton, D. B. (2011). Eddy properties in the California current system. Journal of Geophysical Research (Oceans), 116(C8), 18. doi:10.1029/2010JC006895

Lander, M. A., \& Guard, C. P. (1998). A look a global tropical cyclone activity during 1995: Contrasting high Atlantic activity with low activity in other basins. Monthly Weather Review, 126, 1163-1173.

Lavers, D. A., \& Villarini, G. (2013). The nexus between atmospheric rivers and extreme precipitation across Europe. Geophysical Research Letters, 40, 32593264. doi:10.1002/grl.50636

Lavers, D. A., Villarini, G., Allan, R. P., Wood, E. F., \& Wade, A. J. (2012). The detection of atmospheric rivers in atmospheric reanalyses and their links to British winter floods and the large-scale climatic circulation. Journal of Geophysical Research, 117, D20106. doi: 10.1029/2012JD018027

Liang, J-H., McWilliams, J. C., Kurian, J., Colas, F., Wang, P., \& Uchiyama, Y. (2012). Mesoscale variability in the northeastern tropical Pacific: Forcing mechanisms and eddy properties. Journal of Geophysical Research, 117. doi: 10.1029/2012JC008008

Ma, C.-C., Mechoso, C. R., Robertson, A. W., \& Arakawa, A. (1996). Peruvian stratus clouds and the tropical Pacific circulation: A coupled ocean-atmosphere GCM study. Journal of Climate, 9, 1635-1645.

Madden, R. A., \& Julian, P. R. (1972). Description of global-scale circulation cells in the Tropics with a 40-50 day period. Journal of the Atmospheric Sciences, 29, 1109-1123.

Maddox, R. A., McCollum, D. M., \& Howard, K. W. (1995). Large-scale patterns associated with severe summertime thunderstorms over Central Arizona. Weather and Forecasting, 10, 763-778.

Magaña, V., \& Caetano, E. (2005). Temporal evolution of summer convective activity over the Americas 
warm pools. Geophysical Research Letters, 32. doi: 10.1029/2004GL021033

Magaña, V., Amador, J. A., \& Medina, S. (1999). The MidSummer Drought over México and Central America. Journal of Climate, 12, 1577-1588.

Mahadevan, A. (2014). Ocean science: Eddy effects on biogeochemistry. Nature, 506, 168-169. doi:10.1038/ nature 13048

Maloney, E. D., \& Esbensen, S. K. (2007). Satellite and buoy observations of boreal summer intraseasonal variability in the tropical northeast Pacific. Monthly Weather Review, 135, 3-19.

Mapes, B. E., Liu, P., \& Buenning, N. (2005). Indian Monsoon Onset and the Americas Midsummer Drought: Out-of-Equilibrium Responses to Smooth Seasonal Forcing. Journal of Climate, 18, 1109-1115.

Martin, E., \& Schumacher, C. (2011). Modulation of Caribbean precipitation by the Madden-Julian oscillation. Journal of Climate, 24, 813-824.

Martínez-Castro, D., da Rocha, R. P., Bezanilla-Morlot, A., Alvarez-Escudero, L. J., Reyes-Fernández, P., SilvaVidal, Y., \& Arritt, R. W. (2006). Sensitivity studies of the RegCM3 simulation of summer precipitation, temperature and local wind field in the Caribbean Region. Theoretical and Applied Climatology, 86, 5-22.

Martínez, I., Keigwin, L., Barrows, T. T., Yokoyama, Y., \& Southon, J. (2003). La Niña like conditions in the eastern equatorial Pacific and a stronger Chocó Jet in the northern Andes during the last glaciation. Paleoceanography, 18(2), 1033.

Mechoso, C. R., Robertson, W., Ropelewski, C. F., \& Grimm, A. M. (2005). The American monsoon systems. (The Global Monsoon sSystem: Research and Forecast: Report of the International Committee of the Third International Workshop on Monsoons (IWM-III). 2-6 November 2004, Hangzhou, China). Geneva, Switzerland: World Meteorological Organization.

Méndez, M., \& Magaña, V. (2010). Regional aspects of prolonged meteorological droughts over Mexico and Central America. Journal of Climate, 23, 1175-1188. doi: http://dx.doi.org/10.1175/2009JCLI3080.1

Mesinger, F., DiMe, goG., Kalnay, E., Mitchell, K., Shafran, P. C., Ebisuzaki, W., ... \& Shi, W. (2006). North American regional reanalysis. Bulletin of the American Meteorological Society, 87(3), 343-360.

Mestas-Núñez, A., Enfield, D. B., \& Zhang, C. (2007). Water vapor fluxes over Intra-Americas seasonal and interannual variability and association with rainfall. Journal of Climate, 20, 1910-1922.

Mo, K. C., Chelliah, M., \& Carrera, M. L. (2005). Atmospheric moisture transport over the United States and
Mexico as evaluated in the NCEP regional reanalysis. Journal of Hydrometeorology, 6, 710-728.

Muñoz, E., Busalacchi, A. J., Nigam, S., \& Ruiz-Barradas, A. (2008). Winter and summer structure of the Caribbean Low-Level Jet. Journal of Climate, 21, 1260-1276.

Neiman, P. J., Ralph, F. M., Wick, G. A., Lundquist, J., \& Dettinger, M. D. (2008). Meteorological characteristics and overland precipitation impacts of atmospheric rivers affecting the west coast of North America based on eight years of SSM/I satellite observations. Journal of Hydrometeorology, 9, 22-47.

Neiman, P. J., Schick, L. J., Ralph, F. M., Hughes, M., \& Wick, G. A. (2011). Flooding in western Washington: The connection to atmospheric rivers. Journal of Hydrometeorology, 12, 1337-1358.

Palacios, D. M., \& Bograd, S. J. (2005). A census of Tehuantepec and Papagayo eddies in the northeastern tropical Pacific. Geophysical Research Letters, 32(L23606). doi: 10.1029/2005GL024324.

Peña, M., \& Douglas, M. W. (2002). Characteristics of Wet and Dry Spells over the Pacific side Central America during the rainy season. Monthly Weather Review, 130(12), 3054-3073.

Portig, W. (1965). Central American rainfall. Geographical Review, 55(1), 68-90.

Poveda, G., \& Mesa, O. J. (2000). On the existence of Lloró (the rainiest locality on Earth): Enhanced ocean-land-atmosphere interaction by a low-level jet. Geophysical Research Letters, 27, 1675-1678.

Poveda, G., Mesa, O. J., Salazar, L. F., Arias, P. A., Moreno, H. A., Vieira, S. C., Agudelo, P., Toro, V. G., \& Alvarez, J. F. (2005). Diurnal cycle of precipitation in the tropical Andes of Colombia. Monthly Weather Review, 133(1), 228-240.

Ralph, F. M., Neiman, P. J., \& Wick, G. A. (2004). Satellite and CALJET aircraft observations of atmospheric rivers over the eastern North Pacific Ocean during the winter of 1997/98. Monthly Weather Review, 132, 1721-1745.

Ralph, F. M., Neiman, P. J., \& Rotunno, R. (2005). Dropsonde observations in low-level jets over the northeastern Pacific Ocean from CALJET-1998 and PACJET-2001: Mean vertical-profile and atmospheric-river characteristics. Monthly Weather Review, 133, 889-910.

Ralph, F. M., Neiman, P. J., Wick, G. A., Gutman, S. I., Dettinger, M. D., Cayan, D. R., \& White, A. B. (2006). Flooding on California's Russian River: Role of atmospheric rivers. Geophysical Research Letters, 33 (L13801). doi: 10.1029/2006GL026689

Ralph, F. M., Neiman, P. J., Kiladis, G. N., Weickmann, K., \& Reynolds, D. W. (2011). A multi-scale observational case study of a Pacific atmospheric river 
exhibiting tropical-extratropical connections and a mesoscale frontal wave. Monthly Weather Review, 139, 1169-1189. doi: 10.1175/2010MWR3596.1

Ranjha, R., Svensson, G., Tjernstrom, M., \& Semedo, A. (2013). Global distribution and seasonal variability of coastal low-level jets derived from ERA-Interim reanalysis. Tellus A, 65, 20412. Retrieved from http:// dx.doi.org/10.3402/tellusa.v65i0.20412

Restrepo, J. D., \& Kjerfve, B. (2004). The Pacifc and Caribbean rivers of Colombia: Water discharge, sediment transport, and dissolved loads. In L. D. Lacerda, R. E. Santelli, E. K. Duursma, \& J. J. Abrao (Eds.), Environmental Geochemistry in Tropical and Subtropical Environments (pp. 169-187). Berlin, Germany: Springer Verlag.

Reynolds, R. W., Smith, T. M., Liu, C., Dudley, B., Chelton, K., Casey, S., \& Schlax, M. G. (2007). Daily High-Resolution-Blended Analyses for sea surface temperature. Journal of Climate, 20, 5473-5496.

Rivera, E. R., Domínguez, F., \& Castro, C. L. (2014). Atmospheric rivers and cool season precipitation events in the Verde River basin of Arizona. Journal of Hydrometeorology, 15, 813-829.

Roberge, A., Gyakum, J. R., \& Atallah, E. H. (2009). Analysis of intense poleward water vapor transports into high latitudes of western North America. Weather and Forecasting, 24, 1732-1747.

Roden, G. (1961). On the wind-driven circulation in the Gulf of Tehuantepec and its effect upon surface temperatures. Geofisica Internacional, 3, 55-72.

Romero-Centeno, R., Zavala-Hidalgo, J., \& Raga, G. B. (2006). Midsummer gap winds and low-level circulation over the Eastern Tropical Pacific. Journal of Climate, 20, 3768-3784.

Ropelewski, C. F., Gutzler, D. S., Higgins, R. W., \& Mechoso, C. R. (2005). The North American monsoon system. (The Global Monsoon System: Research and Forecast: Report of the International Committee of the Third International Workshop on Monsoons (IWM-III). 2-6 November 2004, Hangzhou, China). Geneva, Switzerland: World Meteorological Organization.

Saha, S., Moorthi, S., Pan, H. L., Wu, X., Wang, J., Nadiga, S., Tripp, P., Kistler, R., ... \& Goldberg, M. (2010). The NCEP Climate Forecast System Reanalysis. Bulletin of the American Meteorological Society, 91, 1015-1057.

Salinas, J. A. (2006). Dinámica de las ondas del este y su interacción con el flujo medio en el Caribe. (Ph. D. Thesis). Universidad Nacional Autónoma de México, México D.F.

Savijarvi, H., Niemela, S., \& Tisler, P. (2005). Coastal winds and low-level jets: Simulations for sea gulfs.
Quarterly Journal of the Royal Meteorological Society, 131, 625-637. doi: 10.1256/qj.03.177.

Schmitz, J. T., \& Mullen, S. L. (1996). Water vapor transport associated with the summertime North American monsoon as depicted by ECMWF analyses. Journal of Climate, 9, 1621-1634.

Serra, Y. L., Kiladis, G. N., \& Hodges, K. I. (2010). Tracking and mean structure of easterly waves over the Intra-Americas Sea. Journal of Climate, 23(18), 4823-4840.

Serra, Y. L., Jiang, X., Tian, B., Amador-Astúa, J., Maloney, E. D., \& Kiladis, G. N. (2014). Tropical intraseasonal modes of the atmosphere. Annual Review of Environment and Resources, 39, 189-215.

Stohl, A., Forster, C., \& Sodemann, H. (2008). Remote sources of water vapor forming precipitation on the Norwegian west coast at $60^{\circ} \mathrm{N}$ - A tale of hurricanes and an atmospheric river. Journal of Geophysical Research, 113(D05102). doi: 10.1029/2007JD009006

Stumpf, H. G. (1975). Satellite detection of upwelling in the Gulf of Tehuantepec, Mexico. Journal of Physical Oceanography, 5(2), 383-388.

Sugi, M., Noda, A., \& Sato, N., (2002). Influence of the global warming on tropical cyclone climatology: An experiment with the JMA global model. Journal of the Meteorological Society of Japan, 80, 249-272.

Taylor, M. A., Enfield, D. B., \& Chen, A. A. (2002). Influence of the tropical Atlantic versus the tropical Pacific on Caribbean rainfall. Journal of Geophysical Research (Oceans), 107, 3127.

Ubelmann, C., \& Fu, L. L. (2011). Cyclonic eddies formed at the Pacific tropical instability wave fronts. Journal of Geophysical Research, 116(C12). doi:10.1029/2011JC007204

Umatani, S., \& Yamagata, T. (1991). Response of the Eastern Tropical Pacific to meridional migration of the ITCZ: The generation of the Costa Rica Dome. Journal of Physical Oceanography, 21, 346-363.

Uppala, S. M., Kållberg, P. W., Simmons, A. J., Andrae, U., da Costa Bechtold, V., Fiorino, M., Gibson, J. K., Haseler, J., ... \& Woollen, J. (2005). The ERA-40 re-analysis. Quarterly Journal of the Royal Meteorological Society, 131, 2961-3012.

Velázquez-Muñoz, F. A., Martínez, J. A., \& Durazo, R. (2014). Numerical simulation of ocean response by offshore wind stress events. In J. Klapp \& A. Medina (Eds.), Experimental and Computational Fluid Mechanics (pp. 93-110). Geneva, Switzerland: Springer International Publishing.

Ventrice, M. J., Thorncroft, C. D., \& Roundy, P. E. (2011). The Madden-Julian oscillation's influence on African easterly waves and downstream tropical cyclogenesis. Monthly Weather Review, 139, 2704-2722. doi:10.1175/MWR-D-10-05028.1 
Vera, C., Higgins, W., Amador, J. A., Ambrizzi, T., Garreaud, R., Gochis, D., \& Zhang, C. (2006). Toward a unified view of the American monsoon systems. Journal of Climate, 19(20), 4977-5000.

Viale, M., \& Núñez, M. N. (2011). Climatology of winter orographic precipitation over the subtropical central Andes and associated synoptic and regional characteristics. Journal of Hydrometeorology, 12, 481-507.

Wang, C. (2007) Variability of the Caribbean low-level jet and its relations to climate. Climate Dynamics, 29, 411-422.

Wang, C., \& Enfield, D. B. (2001). The tropical Western Hemisphere warm pool. Geophysical Research Letters, 28(8), 1635-1638.

Wang, C., \& Enfield, D. B. (2003). A further study of the tropical Western Hemisphere warm pool. Journal of Climate, 16, 1476-1493.

Wang, C., \& Lee, S.-K. (2007). Atlantic warm pool, Caribbean low-level jet, and their potential impact on Atlantic hurricanes. Geophysical Research Letters, 34(L02703). doi: 10.1029/2006GL028579

Wang, C., Enfield, D. B., Lee S. K., \& Landsea, C. W. (2006). Influences of the Atlantic warm pool on Western Hemisphere summer rainfall and Atlantic hurricanes. Journal of Climate, 19(12), 3011-3028.

Wang, C., Lee, S. K., \& Enfield, D. B. (2008). Climate response to anomalously large and small Atlantic warm pools during the summer. Journal of Climate, 21, 2437.

Wheeler, M. C., \& Hendon, H. H. (2004). An all-season real-time multivariate MJO index: Development of an index for monitoring and prediction. Monthly Weather Review, 132, 1917-1932.

Whyte, F. S., Taylor, M. A., Stephenson, T. S., \& Campbell, J. D. (2008). Features of the Caribbean low level jet. International. Journal of Climatology, 28(1), 119-128.
Willett, C. S., Leben, R., \& Lavín, M. F. (2006). Eddies and tropical instability waves in the eastern tropical Pacific: A review. Progress in Oceanography, 69(2), 218-238.

Xie, S., Xu, H., Kessler, W., \& Nonaka, M. (2005). Air-sea interaction over the eastern Pacific warm pool: Gap winds, thermocline dome, and atmospheric convection. Journal of Climate, 18, 5-20.

Yu, L., Jin, X., \& Weller, R. A. (2008). Multidecade Global Flux Datasets from the Objectively Analyzed Air-sea Fluxes (OAFlux) Project: Latent and Sensible Heat Fluxes, Ocean Evaporation, and Related Surface Meteorological Variables Lisan Yu. (OAFlux Project Tech. Rep. OA-2008-01). Massachusetts, USA: Woods Hole Oceanographic Institution.

Yu, W., Han, W., Maloney, E. D., Gochis, D., \& Xie, S. P. (2011). Observations of eastward propagation of atmospheric intraseasonal oscillations from the Pacific to the Atlantic. Journal of Geophysical Research, 116(D02101). doi: 10.1029/2010JD014336

Zamudio, L., Leonardi, A. P., Meyers S. D., \& O’Brien, J. J. (2001) ENSO and eddies on the southwest coast of Mexico. Geophysical Research Letters, 28(1), 13-16.

Zamudio, L., Hurlburt, H. E., Metzger, E. J., Morey, S. J., O’Brien, J. J., Tilburg, C., \& Zavala-Hidalgo, J. (2006). Interannual variability of Tehuantepec eddies. Journal of Geophysical Research, 11. doi: 10.1029/2005JC003182

Zhang, C. (2005). Madden-Julian oscillation. Reviews of Geophysics, 43(2), RG2003. doi: 10.1029/2004RG000158

Zhu, Y., \& Newell, R. E. (1998). A proposed algorithm for moisture fluxes from atmospheric rivers. Monthly Weather Review, 126, 725-735.

Zuluaga, M. D., \& Poveda, G. (2004). Diagnostics of mesoscale convective systems over Colombia and the eastern tropical Pacific during 1998-2002, Avances en Recursos Hidráulicos, 11, 145-160. 
